\title{
Biomass burning emissions in north Australia during the early dry season: an overview of the 2014 SAFIRED campaign
}

\author{
Marc D. Mallet ${ }^{1}$, Maximilien J. Desservettaz ${ }^{2}$, Branka Miljevic ${ }^{1}$, Andelija Milic ${ }^{1}$, Zoran D. Ristovski ${ }^{1}$, Joel Alroe ${ }^{1}$, \\ Luke T. Cravigan ${ }^{1}$, E. Rohan Jayaratne ${ }^{1}$, Clare Paton-Walsh ${ }^{2}$, David W. T. Griffith ${ }^{2}$, Stephen R. Wilson ${ }^{2}$, \\ Graham Kettlewell ${ }^{2}$, Marcel V. van der Schoot ${ }^{3}$, Paul Selleck ${ }^{3}$, Fabienne Reisen ${ }^{3}$, Sarah J. Lawson ${ }^{3}$, Jason Ward ${ }^{3}$, \\ James Harnwell $^{3}$, Min Cheng ${ }^{3}$, Rob W. Gillett ${ }^{3}$, Suzie B. Molloy ${ }^{3}$, Dean Howard ${ }^{4}$, Peter F. Nelson ${ }^{4}$, \\ Anthony L. Morrison ${ }^{4}$, Grant C. Edwards ${ }^{4}$, Alastair G. Williams ${ }^{5}$, Scott D. Chambers ${ }^{5}$, Sylvester Werczynski ${ }^{5}$, \\ Leah R. Williams ${ }^{6}$, V. Holly L. Winton ${ }^{7, a}$, Brad Atkinson ${ }^{8}$, Xianyu Wang ${ }^{9}$, and Melita D. Keywood ${ }^{3}$ \\ ${ }^{1}$ School of Chemistry, Physics and Mechanical Engineering, Queensland University of Technology, Brisbane, Queensland, \\ 4000, Australia \\ ${ }^{2}$ Centre for Atmospheric Chemistry, University of Wollongong, Wollongong, New South Wales, 2522, Australia \\ ${ }^{3}$ CSIRO Oceans and Atmosphere, Aspendale, Victoria, 3195, Australia \\ ${ }^{4}$ Department of Environmental Sciences, Macquarie University, Sydney, New South Wales, 2109, Australia \\ ${ }^{5}$ Australian Nuclear Science and Technology Organisation, Sydney, New South Wales, 2232, Australia \\ ${ }^{6}$ Aerodyne Research, Inc., Billerica, Massachusetts, 01821, USA \\ ${ }^{7}$ Physics and Astronomy, Curtin University, Perth, Western Australia, 6102, Australia \\ ${ }^{8}$ Bureau of Meteorology, Darwin, Northern Territory, 0810, Australia \\ ${ }^{9}$ Queensland Alliance for Environmental Health Sciences, The University of Queensland, Queensland, 4108, Australia \\ a now at: the British Antarctic Survey, Cambridge, CB3 0ET, UK
}

Correspondence to: Melita Keywood (melita.keywood@csiro.au) and Branka Miljevic (b.miljevic@qut.edu.au)

Received: 28 September 2016 - Discussion started: 10 November 2016

Revised: 5 July 2017 - Accepted: 23 August 2017 - Published: 17 November 2017

\begin{abstract}
The SAFIRED (Savannah Fires in the Early Dry Season) campaign took place from 29 May until 30 June 2014 at the Australian Tropical Atmospheric Research Station (ATARS) in the Northern Territory, Australia. The purpose of this campaign was to investigate emissions from fires in the early dry season in northern Australia. Measurements were made of biomass burning aerosols, volatile organic compounds, polycyclic aromatic carbons, greenhouse gases, radon, speciated atmospheric mercury and trace metals. Aspects of the biomass burning aerosol emissions investigated included; emission factors of various species, physical and chemical aerosol properties, aerosol aging, micronutrient supply to the ocean, nucleation, and aerosol water uptake. Over the course of the month-long campaign, biomass burning signals were prevalent and emissions from several large single burning events were observed at ATARS.

Biomass burning emissions dominated the gas and aerosol concentrations in this region. Dry season fires are extremely
\end{abstract}

frequent and widespread across the northern region of Australia, which suggests that the measured aerosol and gaseous emissions at ATARS are likely representative of signals across the entire region of north Australia. Air mass forward trajectories show that these biomass burning emissions are carried north-west over the Timor Sea and could influence the atmosphere over Indonesia and the tropical atmosphere over the Indian Ocean. Here we present characteristics of the biomass burning observed at the sampling site and provide an overview of the more specific outcomes of the SAFIRED campaign. 


\section{Introduction}

Tropical north Australia is dominated by savannah ecosystems. This region consists of dense native and exotic grasslands and scattered trees and shrubs. Conditions are hot, humid and wet in the summer months of December through March, with hot, dry conditions for the rest of the year giving rise to frequent fires between June and November each year. Human settlements are relatively scarce in northern Australia, outside of the territory capital, Darwin (population of 146000). To the north of the continent are the tropical waters of the Timor Sea, as well as the highly populated Indonesian archipelago. South of the savannah grasslands are the Tanami, Simpson and Great Sandy deserts, spanning hundreds of thousands of square kilometres. Emissions from fires in the savannah regions of northern Australia are therefore the most significant regional source of greenhouse and other trace gases, as well as atmospheric aerosol. Globally, savannah and grassland fires are the largest source of carbon emissions from biomass burning (van der Werf et al., 2010; Shi et al., 2015) and play a significant role in the Earth's radiative budget. It is therefore important to quantify, characterise and fully understand the emissions from savannah fires in northern Australia, taking into account the complexity, variability and diversity of the species emitted.

In Australia approximately $550000 \mathrm{~km}^{2}$ of tropical and arid savannahs burn each year (Meyer et al., 2012; RussellSmith et al., 2007), representing $7 \%$ of the continent's land area. In the tropical north of Australia, the fires during the early dry season in May/June consist of naturally occurring and accidental fires, as well as prescribed burns under strategic fire management practice to reduce the frequency and intensity of more extensive fires in the late dry season in October and November (Andersen et al., 2005). These fires in the early dry season burn with a low to moderate intensity and are normally confined to the grass layer. Events where fires reach the canopy level are rare. These prescribed burns are an important process for the region and are undertaken by local landholders with permits, as well as government supported bodies and volunteers. There has been a recent push to reinstate traditional Aboriginal fire management regimes in this region (Russell-Smith et al., 2013). Other fire management regimes are implemented in similar environments around the world, such as the savannah ecosystems of Africa (Govender et al., 2006) or the chaparral grasses in the United States (Akagi et al., 2012). In general, fire management regimes are considered to benefit regional biodiversity and can lead to the long-term increase in living biomass, resulting in a reduction of greenhouse gas emissions (Russell-Smith et al., 2013). Quantifying the emissions from dry season fires on regional scales is essential for understanding the impact of these fires on the local and global atmosphere.

The components and concentrations of emissions from savannah fires are dependent upon the vegetation and burning conditions. While $\mathrm{CO}_{2}$ is the primary product of biomass burning (BB), combustion processes also result in the emission of many other trace gases such as $\mathrm{CO}, \mathrm{CH}_{4}, \mathrm{NOx}, \mathrm{N}_{2} \mathrm{O}$ and non-methane organic compounds (NMOCs) and aerosol particles composed of elemental carbon, organic carbon and some inorganic material (Crutzen and Andreae, 1990). The state of organics in biomass burning aerosols can vary significantly due to the type of plant material burned and the characteristics of the fires themselves, as well as through aging processes in the atmosphere.

The effects of these emissions on radiative forcing are complex. The global average radiative forcing due to biomass burning aerosol-radiation interaction is estimated in the 5th International Panel on Climate Change report as $0.0 \mathrm{~W} \mathrm{~m}^{-2}$ with an uncertainty range of -0.20 to $+0.20 \mathrm{~W} \mathrm{~m}^{-2}$ (Bindoff et al., 2013). It is well known that greenhouse gases have a positive radiative forcing, heating up the atmosphere. Light-absorbing carbon in the aerosol phase will also result in a positive radiative forcing (Jacobson, 2001) by absorbing shortwave radiation. Conversely, the presence of aerosol organic and inorganic matter can result in a negative radiative forcing by scattering solar radiation (Penner et al., 1998). In addition, biomass burning has been shown to be a significant source of cloud condensation nuclei ( $\mathrm{CCN})$, despite typically being composed of weakly hygroscopic substances (Lawson et al., 2015), due to the high number of particles emitted. This can result in a change in cloud droplet concentrations and volume, thereby influencing cloud formation, albedo and lifetime. The contribution of each species to the overall radiative forcing is also likely to change as smoke plumes age (Liousse et al., 1995). Furthermore, not all biomass burning aerosol will interact with radiation in the same way. For example, fresh BB emissions in the tropics has been observed to be more absorbing than those from boreal forest fires (Wong and $\mathrm{Li}, 2002$ ). The role of biomass burning emissions is not limited to the Earth's radiative budget. Certain species of emissions (e.g. mercury) can be deposited and sequestered in soil (Gustin et al., 2008), vegetation (Rea et al., 2002) or bodies of water (LaRoche and Breitbarth, 2005).

Large-scale studies in Africa (Keil and Haywood, 2003), North America (Yokelson et al., 2009; Singh et al., 2006), Europe (Saarikoski et al., 2007), South America (Ferek et al., 1998) and Asia (Lin et al., 2013; Du et al., 2011) have provided valuable insight into the impact of fire emissions on the regional atmosphere and laboratory measurements have proved to be useful in understanding the emission factors, composition and atmospheric processing of these emissions (Stockwell et al., 2014). Despite this, there is still a need for a better scientific understanding of the influence biomass burning has on atmospheric composition and air quality (Kaiser and Keywood, 2015), particularly around Australia. Furthermore, the tropics are disproportionately under-sampled and the atmospheric and ocean processes in these regions are of both regional and global consequence. The SAFIRED campaign will contribute towards better understanding biomass 
burning emissions and the atmospheric composition in tropical Australia.

On a more specific level, the SAFIRED campaign was undertaken with the following objectives:

- To obtain Australian savannah fire dry season emission factors for greenhouse gases, polycyclic aromatic hydrocarbons, gaseous elemental mercury, non-methane organic compounds, Aitken- and accumulation-mode aerosols and non-refractory submicron organic, sulfates, ammonia, nitrates and chlorides.

- To understand the emission of mercury from north Australian fires and to quantify the delivery of mercury to the ecosystem.

- To characterise the composition and size of aerosols in the region of north Australia and to understand the influence and extent of biomass burning on the total aerosol burden.

- To assess the ability of biomass burning aerosol to act as cloud condensation nuclei and to establish a link between aerosol composition, size and $\mathrm{CCN}$.

- To assess the fractional solubility of aerosol iron and other trace metals in this region in the context of the potential supply of micronutrients required for marine primary production in the ocean.

\section{Description of experiment}

\subsection{Site}

The Australian Tropical Atmospheric Research Station (ATARS; $12^{\circ} 14^{\prime} 56.6^{\prime \prime} \mathrm{S}, 131^{\circ} 02^{\prime} 40.8^{\prime \prime} \mathrm{E}$ ) is located on the Gunn Point Peninsula in northern Australia (see Fig. 1). ATARS is operated by the Australian Bureau of Meteorology and the CSIRO (Commonwealth Scientific and Industrial Research Organisation). Standard meteorological measurements (wind velocity, atmospheric pressure, precipitation) run permanently at ATARS and two laboratories are in place for the installation of other instruments. The SAFIRED campaign took place from 29 May until 30 June 2014, with personnel and instruments from nine institutes utilising these laboratories to make comprehensive gaseous and aerosol measurements during this period of the early dry season.

\subsection{Instruments and measurements}

\subsubsection{Trace Gases}

\section{Greenhouse gases}

Continuous measurement of $\mathrm{CO}_{2}, \mathrm{CO}, \mathrm{CH}_{4}$ and $\mathrm{N}_{2} \mathrm{O}$ were made using a high-precision Fourier transform infrared (FTIR) trace gas and isotope Spectronus analyser, developed by the Centre for Atmospheric Chemistry at the University of Wollongong. The analyser combines an FTIR spectrometer (Bruker IRcube), a pressure- and temperature-controlled multi-pass cell and an electronically cooled mercury cadmium telluride detector. A detailed description of the instrument and concentration retrieval technique are available in Griffith et al. (2012) and Griffith (1996).

\section{Ozone and other trace gases}

A multi-axis differential optical absorption spectrometer (MAX-DOAS) was installed on the top of one of the laboratories during the campaign. The technique has been shown to provide the vertical profile of nitrogen dioxide, ozone, sulfur dioxide, formaldehyde, glyoxal and aerosol extinction (Sinreich et al., 2005; Hönninger et al., 2004). The MAXDOAS instrument used in this campaign was designed and built at the University of Wollongong. It consists of a vertically rotating prism capturing scattered solar radiation at different angles $\left(1,2,4,8,16,30\right.$ and a reference at $\left.90^{\circ}\right)$ into a fibre optic that carries the radiation to a UV-visible spectrometer (AvaSpec - ULS3648). Furthermore, a Thermo Scientific model 49i UV photometric ozone analyser was used to measure ozone concentrations. Several periods of elevated biomass burning emissions resulted in interferences with the 49i UV analyser and were removed from the analyses. These periods were marked with strong correlations with high concentrations of acetonitrile and other UV-absorbing species, such as certain polycyclic aromatic hydrocarbon (PAH) species.

\section{Non-methane organic compounds}

Online NMOC measurements were made using a highsensitivity proton transfer reaction mass spectrometer (PTRMS; Ionicon Analytik) using $\mathrm{H}_{3} \mathrm{O}^{+}$as the primary ion. The inlet was $10 \mathrm{~m}$ in length and drew air at $5 \mathrm{~L} \mathrm{~min}^{-1}$ from $2 \mathrm{~m}$ above the roof (approx $5.5 \mathrm{~m}$ above ground level). The PTRMS ran with inlet and drift tube temperature of $60^{\circ} \mathrm{C}, 600 \mathrm{~V}$ drift tube, and 2.2 mbar drift tube pressure, which equates to an energy field of $135 \mathrm{Td}$. The PTR-MS sequentially scanned masses 15-190, with $1 \mathrm{~s}$ dwell time. The PTR-MS operated with the aid of auxiliary equipment which regulates the flow of air in the sample inlet and controls whether the PTR-MS is sampling ambient or zero air or calibration gas (Galbally et al., 2007).

Furthermore, AT VOC (adsorbent tube volatile organic compound) samples were collected by an automatic VOC sequencer which actively draws air through two multi-adsorbent tubes in series (Markes Carbograph 1TD/Carbopack X). The adsorbent tubes were then analysed by a PerkinElmer TurboMatrix ${ }^{\mathrm{TM}} 650$ ATD (automated thermal desorber) and a Hewlett Packard 6890A gas chromatograph (GC) equipped with a flame ionisation detector (FID) and a mass-selective detector (MSD) at CSIRO Oceans and 
Table 1. A summary of the quantities measured during SAFIRED and the respective instrument or measurement technique. Detection limits and uncertainties are expressed for select instruments or measurements.

\begin{tabular}{|c|c|c|c|c|c|}
\hline Quantity & Instrument or technique & $\begin{array}{l}\text { Sample } \\
\text { frequency }\end{array}$ & Reference & Detection limits & Uncertainties \\
\hline $\mathrm{CO}, \mathrm{CO}_{2}, \mathrm{CH}_{4}$ and $\mathrm{N}_{2} \mathrm{O}$ & $\begin{array}{l}\text { Fourier transform infrared spec- } \\
\text { trometry }\end{array}$ & $3 \min$ & $\begin{array}{l}\text { Griffith et al. } \\
(2012)\end{array}$ & $\begin{array}{l}0.04 \mathrm{mg} \mathrm{CO}_{2} \mathrm{~m}^{-2} \mathrm{~s}^{-1}, \\
20 \mathrm{ngN} \mathrm{m}^{-2} \mathrm{~s}^{-1} \\
\left(\mathrm{~N}_{2} \mathrm{O}\right), \\
\left.30 \mathrm{ng} \mathrm{CH}_{4} \mathrm{~m}^{-2} \mathrm{~s}^{-1}\right)\end{array}$ & $\begin{array}{l}0.02\left(\mathrm{CO}_{2}\right), \quad 0.2 \\
\left(\mathrm{CH}_{4}\right), 0.1\left(\mathrm{~N}_{2} \mathrm{O}\right), \\
0.2(\mathrm{CO})^{\mathrm{a}}\end{array}$ \\
\hline $\mathrm{O}_{3}$ & UV Photometric Ozone Analysis & $1 \mathrm{~min}$ & & $0.50 \mathrm{ppb}$ & $\sim 1 \mathrm{ppb}$ \\
\hline $\begin{array}{l}\text { Non-methane organic } \\
\text { compounds }\end{array}$ & $\begin{array}{l}\text { Proton transfer mass spectrome- } \\
\text { try, high-performance liquid chro- } \\
\text { matography of Supelco cartridge } \\
\text { samples; gas chromatography of ad- } \\
\text { sorbant tubes }\end{array}$ & $\begin{array}{l}3 \mathrm{~min} ; 12 \mathrm{~h} \\
12 \mathrm{~h}\end{array}$ & $\begin{array}{l}\text { Galbally et al. } \\
\text { (2007); Cheng et } \\
\text { al. (2016); Lawson } \\
\text { et al. } \\
\text { (2015); Dunne et } \\
\text { al. (2017) }\end{array}$ & $\begin{array}{l}2-563 \mathrm{ppt} \quad \text { (PTR-MS } \\
\text { ions) }\end{array}$ & $\begin{array}{l}<22 \% \quad \text { (PTR-MS } \\
\text { ions) }\end{array}$ \\
\hline $\begin{array}{l}\text { Polycyclic aromatic hy- } \\
\text { drocarbons (gas and par- } \\
\text { ticle phase) }\end{array}$ & $\begin{array}{l}\text { Gas chromatography and high- } \\
\text { resolution mass spectrometry of } \\
\text { filter and foam samples }\end{array}$ & $24 \mathrm{~h}$ & Wang et al. (2017) & $<1 \mathrm{pg} \mathrm{m}^{-3}$ & $< \pm 20 \%$ (rep) \\
\hline $\begin{array}{l}\text { Gaseous elemental mer- } \\
\text { cury; gaseous oxidised } \\
\text { mercury; and particulate- } \\
\text { bound mercury }\end{array}$ & $\begin{array}{l}\text { Cold-vapour atomic fluorescence } \\
\text { spectroscopy }\end{array}$ & $5 \mathrm{~min} ; 2 \mathrm{~h} ; 2 \mathrm{~h}$ & $\begin{array}{l}\text { Landis et al. } \\
(2002) \text {; Steffen et } \\
\text { al. (2008) }\end{array}$ & $\begin{array}{l}0.1 \mathrm{ng} \mathrm{m}^{-3} \quad(\mathrm{GEM}) \\
2 \mathrm{pg} \mathrm{m}^{-3} \quad(\mathrm{GOM}) \\
2 \mathrm{pg} \mathrm{m}^{-3}(\mathrm{PBM})\end{array}$ & WmN.R. ${ }^{b}$ \\
\hline Radon & $700 \mathrm{~L}$ dual-flow two filter detector & $1 \mathrm{~h}$ & $\begin{array}{l}\text { Chambers et al. } \\
\text { (2014) }\end{array}$ & $\pm 0.04 \mathrm{~Bq} \mathrm{~m}^{-3}$ & $10-14 \%$ \\
\hline $\begin{array}{l}\text { Aerosol mobility size } \\
\text { distributions ( } 14 \text { to } \\
670 \mathrm{~nm}) \text {; neutral and } \\
\text { charged aerosol size } \\
\text { distributions ( } 0.8 \text { to } \\
42 \mathrm{~nm})\end{array}$ & $\begin{array}{l}\text { Scanning mobility particle sizer, } \\
\text { neutral cluster and air ion spectrom- } \\
\text { etry }\end{array}$ & $5 \mathrm{~min} ; 4 \mathrm{~min}$ & Mirme et al. (2007) & - & $\begin{array}{l} \pm 1 \% \text { in size se- } \\
\text { lection, } \pm 10 \% \text { in } \\
\text { CPC counts }\end{array}$ \\
\hline $\begin{array}{l}\text { Cloud condensation } \\
\text { nuclei concentration (at } \\
0.5 \% \text { supersaturation) }\end{array}$ & $\begin{array}{l}\text { Supersaturated streamwise } \\
\text { continuous-flow of aerosols in } \\
\text { a wetted column using thermal gra- } \\
\text { dient followed by optical particle } \\
\text { counting of activated CCN }\end{array}$ & $10 \mathrm{~s}$ & Fedele (2015) & - & $\begin{array}{l} \pm 0.1 \% \mathrm{SS}, \pm 20 \% \\
\text { in OPC counts }\end{array}$ \\
\hline $\begin{array}{l}\text { Elemental and organic } \\
\text { carbon; water soluble } \\
\text { ions; and anhydrous } \\
\text { sugars }\left(\mathrm{PM}_{1} \text { and } \mathrm{PM}_{10}\right)\end{array}$ & $\begin{array}{l}\beta+\text { attenuation; ion chromatog- } \\
\text { raphy; high-performance anion- } \\
\text { exchange chromatography }\end{array}$ & $12 \mathrm{~h}$ & $\begin{array}{l}\text { Chow et al. (2007); } \\
\text { Iinuma et al. (2009) }\end{array}$ & $\begin{array}{l}0.0009 \mu \mathrm{g} \mathrm{m}^{-3} \quad \text { (ox- } \\
\text { alate), } 0.0002 \mu \mathrm{g} \mathrm{m}^{-3} \\
\text { (levoglucosan) }\end{array}$ & N.R. \\
\hline $\begin{array}{l}\text { Soluble and total fraction } \\
\text { of trace metals }\left(\mathrm{PM}_{10}\right)\end{array}$ & $\begin{array}{l}\text { High-resolution inductively coupled } \\
\text { plasma mass spectrometry analysis } \\
\text { of extracted leachates and digests }\end{array}$ & $24 \mathrm{~h}$ & $\begin{array}{l}\text { Winton et al. } \\
(2016)\end{array}$ & $<1 \mathrm{pg} \mathrm{m}^{-3}$ & $\begin{array}{l} \pm 5 \% \text { in soluble } \mathrm{Fe} \\
\pm 3 \% \text { in total } \mathrm{Fe}\end{array}$ \\
\hline $\begin{array}{l}\text { Non-refractory chemical } \\
\text { composition }\left(\mathrm{PM}_{1}\right)\end{array}$ & $\begin{array}{l}\text { Time-of-flight aerosol mass spec- } \\
\text { trometry }\end{array}$ & $3 \min$ & $\begin{array}{l}\text { Drewnick et al. } \\
(2005)\end{array}$ & $\begin{array}{l}0.003 \mu \mathrm{g} \mathrm{m}^{-3}\left(\mathrm{NO}_{3}^{-},\right. \\
\left.\mathrm{SO}_{4}^{2-}\right), \quad 0.03 \mu \mathrm{g} \mathrm{m}^{-3} \\
\left(\mathrm{NH}_{4}^{+}, \text {organics }\right)\end{array}$ & $\sim \pm 20 \%$ \\
\hline $\begin{array}{l}\text { Aerosol volatility and } \\
\text { hygroscopicity (50 and } \\
150 \mathrm{~nm})\end{array}$ & $\begin{array}{l}\text { Volatility and hygroscopicity tan- } \\
\text { dem differential mobility analysis }\end{array}$ & $\begin{array}{l}12 \min \\
\text { cycle) }\end{array}$ (full & $\begin{array}{l}\text { Johnson et al. } \\
\text { (2004) }\end{array}$ & -4 & $\begin{array}{l} \pm 1 \% \text { in size selec- } \\
\text { tion, } \pm 1 \% \\
\text { in } \mathrm{RH}, \pm 3 \% \text { in } \\
\text { thermodenuder } \\
\text { temperature }\end{array}$ \\
\hline
\end{tabular}

${ }^{\mathrm{a}}$ Uncertainty expressed as measurement precision (Allan deviation) for $1 \mathrm{~min}$, expressed in $\mu \mathrm{mol} \mathrm{mol}^{-1}$. ${ }^{\mathrm{b}}$ To be discussed in future work. N.R.: not reported.

Atmosphere laboratories. Further details of the sampling and analyses are given in Cheng et al. (2016).

During sampling, carbonyls and dicarbonyls were trapped on S10 Supelco cartridges, containing high-purity silica adsorbent coated with 2,4-dinitrophenylhydrazine (DPNH), where they were converted to the hydrazone derivatives. Samples were refrigerated immediately after sampling until analysis. The derivatives were extracted from the cartridge in $2.5 \mathrm{~mL}$ of acetonitrile and analysed by high-performance liquid chromatography with diode array detection. The diode array detection enables the absorption spectra of each peak to be determined. The difference in the spectra highlights which peaks in the chromatograms are mono- or dicarbonyl DPNH derivatives and, along with retention times, allows the identification of the dicarbonyls glyoxal and methylglyoxal. Further details can be found in Lawson et al. (2015). 


\section{PAHs}

PAHs were sampled through a high-volume air sampler (Kimoto Electric Co., Ltd.) using a sampling rate typically at $\sim 60 \mathrm{~m}^{-3} \mathrm{~h}^{-1}$. The sampling rate was calibrated using an orifice plate prior to the sampling campaign and the sampling volume was calculated based on the calibrated sampling rate and sampling duration. A bypass gas meter installed on the sampler was used to monitor any anomalous fluctuation of the sampling rate during the sampling period. Particleassociated and gaseous PAHs were collected on glass fibre filters (Whatman ${ }^{\mathrm{TM}}, 203 \times 254 \mathrm{~mm}$, grade GF/A in sheets) and subsequent polyurethane foam plugs respectively. The glass fibre filters and polyurethane foam, along with the field blank samples, were extracted separately using an accelerated solvent extractor (Thermo Scientific ${ }^{\mathrm{TM}}$ Dionex ${ }^{\mathrm{TM}} \mathrm{ASE}^{\mathrm{TM}}$ 350) after being spiked with a solution containing 7 deuterated PAHs (i.e. ${ }^{2} \mathrm{D}_{10}$-phenanthrene, ${ }^{2} \mathrm{D}_{10}$-fluoranthene, ${ }^{2} \mathrm{D}_{12}$-chrysene, $\quad{ }^{2} \mathrm{D}_{12}$-benzo[ $b$ ]fluoranthene, $\quad{ }^{2} \mathrm{D}_{12}$-BaP, ${ }^{2} \mathrm{D}_{12}$-indeno[1,2,3-cd]pyrene, $\quad{ }^{2} \mathrm{D}_{12}$-benzo[ $\left.g, h, i\right]$ perylene) at different levels as internal standards for quantification purposes. Concentrated extracts were cleaned up by neutral alumina and neutral silica. Eluents were carefully evaporated to near dryness and refilled with $250 \mathrm{pg}$ of ${ }^{13} \mathrm{C}_{12}$-PCB (polychlorinated biphenyl) 141 (in $25 \mu \mathrm{L}$ isooctane) employed as the recovery/instrument standard for estimating the recoveries of the spiked internal standards and monitoring the performance of the analytical instrument. Samples were analysed using a Thermo Scientific ${ }^{\mathrm{TM}}$ TRACE $^{\mathrm{TM}}$ 1310 gas chromatograph coupled to a Thermo Scientific ${ }^{\mathrm{TM}}$ double-focusing system magnetic sector high-resolution mass spectrometer (HRMS). The HRMS was operated in electron impact-multiple ion detection mode and resolution was set to $\geq 10000$ (10\% valley definition). An isotopic dilution method was used to quantify 13 PAH analytes including phenanthrene, anthracene, fluoranthene, pyrene, benzo $[a]$ anthracene, chrysene, benzo $[b]$ fluoranthene, benzo $[k]$ fluoranthene, benzo[ $e]$ pyrene, $\mathrm{BaP}$, indeno[1,2,3$c d]$ pyrene, dibenzo $[a, h]$ anthracene, benzo $[g, h, i]$ perylene.

\section{Mercury}

Total gaseous mercury, i.e. gaseous elemental mercury + gaseous oxidised mercury (TGM; GEM + GOM), was sampled from a $10 \mathrm{~m}$ mast and measured via gold pre-concentration and cold-vapour atomic fluorescence spectroscopy using a Tekran 2537X instrument. Simultaneously, GEM, GOM and particulate-bound mercury (PBM) were individually measured using a Tekran 2537B connected to a combined Tekran 1130/1135 speciation unit sampling at a $5.4 \mathrm{~m}$ height. The sampling train of the 1130/1135 collects first GOM (KCl-coated denuder) then PBM (quartz wool pyrolyser) in series from a $10 \mathrm{~L} \mathrm{~min}^{-1}$ sampling flow, allowing GEM only to flow onwards for detection by subsampling by the 2537B. Due to the small atmospheric concen- trations of GOM and PBM, pre-concentration occurred over a $1 \mathrm{~h}$ period with subsequent analysis taking an additional hour. Continuous measurements of GEM at $5 \mathrm{~min}$ resolution were made possible for the $2537 \mathrm{~B}$ unit by rotating preconcentration/analysis roles of the two internal gold traps. Both 2537 units sampled at $1 \mathrm{~L} \mathrm{~min}^{-1}$ and were calibrated every $23 \mathrm{~h}$ using an internal mercury permeation source. For more information on the 2537 and 1130/1135 systems see Landis et al. (2002) and Steffen et al. (2008).

GEM fluxes were measured using the methods outlined in Edwards et al. (2005). Air samples were drawn at heights of 5.2 and $8.0 \mathrm{~m}$ through $46.4 \mathrm{~m}$ of nylon tubing using a PTFE diaphragm pump operating at $10 \mathrm{~L} \mathrm{~min}^{-1}$. Subsampling from this flow through a $0.2 \mu \mathrm{m}$ PTFE filter at $1 \mathrm{~L} \mathrm{~min}^{-1}$ by a Tekran 2537A, and switching between sample intakes, allowed resolution of a GEM gradient every $30 \mathrm{~min}$. The transfer velocity was measured using a Campbell Scientific CSAT3 sonic anemometer and LI-COR 7200 closed-path infrared gas analyser for $\mathrm{CO}_{2}$, both located on the same tower as the gradient intakes at $6.6 \mathrm{~m}$ and sampling at $20 \mathrm{~Hz}$.

\section{Radon}

In order to measure radon concentrations, a $700 \mathrm{~L}$ dual-flowloop two-filter radon detector, designed and built by the Australian Nuclear Science and Technology Organisation (Whittlestone and Zahorowski, 1998; Chambers et al., 2014), was installed at ATARS in 2011 and has been fully operational since July 2012. The detector provided continuous hourly radon concentrations for the duration of the SAFIRED campaign, sampling air at $40 \mathrm{~L} \mathrm{~min}^{-1}$ from $12 \mathrm{~m}$ above ground level through $25 \mathrm{~mm}$ high-density polyethylene agricultural pipe. A coarse aerosol filter and dehumidifier were installed "upstream" of the detector, as well as a $400 \mathrm{~L}$ delay volume to ensure that thoron $\left({ }^{220} \mathrm{Rn}\right.$, half-life $\left.55 \mathrm{~s}\right)$ concentrations in the inlet air stream were reduced to less than $0.5 \%$ of their ambient values. The detector's response time is around $45 \mathrm{~min}$, and the lower limit of detection is $40-50 \mathrm{mBq} \mathrm{m}^{-3}$. Calibrations are performed on a monthly basis by injecting radon from a PYLON $101.15 \pm 4 \% \mathrm{kBq}$ Ra-226 source $\left(12.745 \mathrm{~Bq} \mathrm{~min}^{-1}{ }^{222} \mathrm{Rn}\right)$, traceable to NIST standards, and instrumental background is checked every 3 months. In postprocessing, half-hourly raw counts were integrated to hourly values before calibration to activity concentrations $\left(\mathrm{Bq} \mathrm{m}^{-3}\right)$.

\subsubsection{Aerosols}

\section{Aerosol drying system}

An automated regenerating aerosol diffusion dryer (ARADD) is permanently installed on the roof of the laboratory containing the aerosol instrumentation for this campaign. This was used in front of the aerosol manifold to continuously dry the aerosol sample. The ARADD design, similar to that described by Tuch et al. (2009), continuously 
conditions the aerosol sample to a relative humidity of below $40 \%$ with maximum aerosol transmission efficiency. The ARADD utilises two diffusion drying columns in parallel, each containing seven stainless-steel mesh tubes of $10 \mathrm{~mm}$ internal diameter and approximately $800 \mathrm{~mm}$ length, surrounded by a cavity packed with silica gel. The aerosol sampled is directed into one column at a time, while the other column is regenerated by an ultra-dry compressed air system. All flows are controlled by software that directs sample flow and compressed air flow to the appropriate column with a series of valves. The ARADD has total suspended particulate style intake at the inlet of the aerosol sample path. This is a non-size-selective stainless-steel inlet with a semi-circular hat over an inverted conical funnel of variable pitch ending with a $3 / 4$ in. stainless-steel tube. In practice, the aerosols collected have an equivalent aerodynamic diameter of $100 \mu \mathrm{m}$ or less depending on sampling conditions. The inlet led to a sample manifold at the exit of the system to provide sampling take-offs for the various aerosol instruments connected to the ARADD. Flow through the ARADD is provided by the instruments and pumps connected downstream. The ambient and inlet relative humidity for the entire sampling period were logged and are displayed in Supplement Fig. S1.

\section{Aerosol size}

Aerosol size distributions were measured with a scanning mobility particle sizer (SMPS). A TSI 3071 long-column electrostatic classifier with a TSI 3772 condensation particle counter (CPC) measured the size distribution over a range of 14 to $670 \mathrm{~nm}$ at a scan interval of $5 \mathrm{~min}$.

In addition to the aerosol size distributions measured by the SMPS, neutral and charged aerosol particle distributions from 0.8 to $42 \mathrm{~nm}$ were measured using a neutral cluster and air ion spectrometer (NAIS; Manninen et al., 2009; Mirme et al., 2007). In this study, the NAIS was set to operate in a cycle of 4 min including ion and neutral particle sampling periods of 2 and $1 \mathrm{~min}$, respectively, with the remaining minute being an offset period which is required to neutralise and relax the electrodes. The total sampling air flow was $60 \mathrm{~L} \mathrm{~min}^{-1}$, the high flow rate being used to minimise ion diffusion losses and maximise the measured ion concentration sensitivity. Ion losses are accounted for during post-processing of the data by the software (Mirme et al., 2007).

\section{Aerosol composition and water uptake}

$\mathrm{PM}_{1}$ and $\mathrm{PM}_{10} 12 \mathrm{~h}$ filter samples (night and day) were collected on a TAPI 602 Beta plus particle measurement system (BAM). Portions of the $\mathrm{PM}_{1}$ filters have been analysed for elemental and organic carbon mass loadings using a DRI model 2001A thermal-optical carbon analyser following the IMPROVE-A temperature protocol (Chow et al., 2007). Additional portions of the $\mathrm{PM}_{1}$ filters were extracted in $5 \mathrm{~mL}$ of $18.2 \mathrm{~m} \Omega$ de-ionised water and preserved using $1 \%$ chloroform. These extracts have been analysed for major watersoluble ions by suppressed ion chromatography and for anhydrous sugars including levoglucosan by high-performance anion-exchange chromatography with pulsed amperometric detection (Iinuma et al., 2009).

Daily aerosol filters were collected using two Ecotech 3000 high-volume volumetric flow-controlled aerosol samplers with $\mathrm{PM}_{10}$ size selective inlets. One high-volume sampler was used to collect aerosols on acid-cleaned Whatman 41 filters to determine the soluble and total fraction of trace metals. Soluble trace metals were extracted from a filter aliquot using ultra-pure water $(>18.2 \mathrm{~m} \Omega)$ leaching experiments. Total trace metal concentrations were determined by digesting a second filter aliquot with concentrated nitric and hydrofluoric acids. Leachates and digested solutions were analysed by high-resolution inductively couple plasma mass spectrometry. The second sampler was used to collect a set of aerosol samples on quartz filters for elemental and organic carbon analysis following (Chow et al., 2007) and major anion and cation analysis.

The volatility and hygroscopicity of 50 and $150 \mathrm{~nm}$ particles were measured with a custom-built volatility and hygroscopicity tandem differential mobility analyser ( $\mathrm{VH}-$ TDMA). Inlet dried particles were size-selected (alternating between 50 and $150 \mathrm{~nm}$ ) using a TSI 3080 electrostatic classifier. Scans alternated between two different sample pathways. In the first, after size selection, particles were passed through a thermodenuder set to $120^{\circ} \mathrm{C}$. The sample line was then split so that half went to an SMPS comprised of a TSI 3080 classifier and a TSI 3010 CPC (V-TDMA). The rest of the sample was passed through a humidifying system that exposed the particles to a relative humidity of $90 \%$ before being brought into another SMPS with a 3080 classifier and 3010 CPC (H-TDMA). Alternatively, the thermodenuder was bypassed in every second scan so that the V-TDMA was used to verify the size selection and the H-TDMA was able to observe the hygroscopic growth of ambient particles. Each scan ran for $3 \mathrm{~min}$, giving a full set of data every $12 \mathrm{~min}$.

The chemical composition and properties of nonrefractory submicron particles were investigated with a compact time-of-flight aerosol mass spectrometer (cToF-AMS, Aerodyne Research, Inc.) and a time-of-flight aerosol chemical speciation monitor (ToF-ACSM, Aerodyne Research, Inc.). Both of these instruments operate with the same principle and have many identical components. An aerodynamic lens in the inlet of each instrument focuses the particles into a beam and differential pumping removes most of the gas phase. Particles are flash-vaporised at $600^{\circ} \mathrm{C}$ and ionised by electron impact before passing through a time-of-flight mass spectrometer to a multi-channel plate detector in the cToFAMS and a dynode detector in the ToF-ACSM. The cToFAMS has the added benefit of having a particle time-of-flight (pToF) mode, which allows the size resolved chemical composition to be measured. Both instruments sampled through 
a $\mathrm{PM}_{2.5}$ inlet and Nafion dryer. In addition, the inlet of the cToF-AMS was incorporated into the VH-TDMA system, so that when the VH-TDMA was measuring ambient particles, the cToF-AMS would draw particles through the thermodenuder set at $120^{\circ} \mathrm{C}$ and vice versa. This gives additional information about the chemical composition of the volatile component of submicron particles.

The number of particles activated to cloud droplets was measured using a continuous-flow stream-wise thermal gradient cloud condensation nuclei counter (CCNC) from Droplet Measurement Technologies Inc. (DMT, model no. 100). Particles were exposed to a $0.5 \%$ supersaturation and activated particles greater than $1 \mu \mathrm{m}$ were counted with an optical particle counter using a $50 \mathrm{~mW}, 658 \mathrm{~nm}$ laser diode.

\section{Back trajectories}

Hourly 10-day air mass back trajectories terminating at ATARS were produced using the NOAA HYSPLIT model (Draxler and Rolph, 2011) and catalogued in a database for use with the SAFIRED campaign data set. Global Data Assimilation System input files with $0.5^{\circ}$ resolution were obtained from the NOAA ARL FTP site (http://ready.arl.noaa. gov/gdas1.php) to drive the HYSPLIT model.

\section{Satellite detection of fires}

Data on the location of fires was collected from the Australian national bushfire monitoring system, Sentinel Hotspots. Hotspot locations are derived from the Moderate Resolution Imaging Spectroradiometer (MODIS) sensors on the Terra and Aqua satellites and the Visible Infrared Imaging Radiometer Suite (VIIRS) sensor on the Suomi NPP satellite. The Terra, Aqua and Suomi NPP satellites fly over the region around ATARS at approximately 10:30, 15:00 and 14:30, respectively. Detection of fires is therefore limited to those that are flaming during these times.

\section{Overview of campaign}

\subsection{Fires and air masses}

Thousands of fires were observed during the period of the SAFIRED campaign in Australia by the MODIS and VIIRS sensors on the Terra and Aqua NASA satellites. The vast majority of these occurred in the savannah regions of northern Australia. Over 28000 fires were detected within $400 \mathrm{~km}$ of ATARS during the sampling period. Air mass back trajectories from the sampling site show that air masses over the study period predominately originated from the southeast (see Fig. 1), generally over the regions where fires were frequently detected. Considering the daily satellite observations of close and distant fires, as well as meteorological, gaseous and aerosol measurements over the duration of SAFIRED, five periods were distinguished: four biomass-

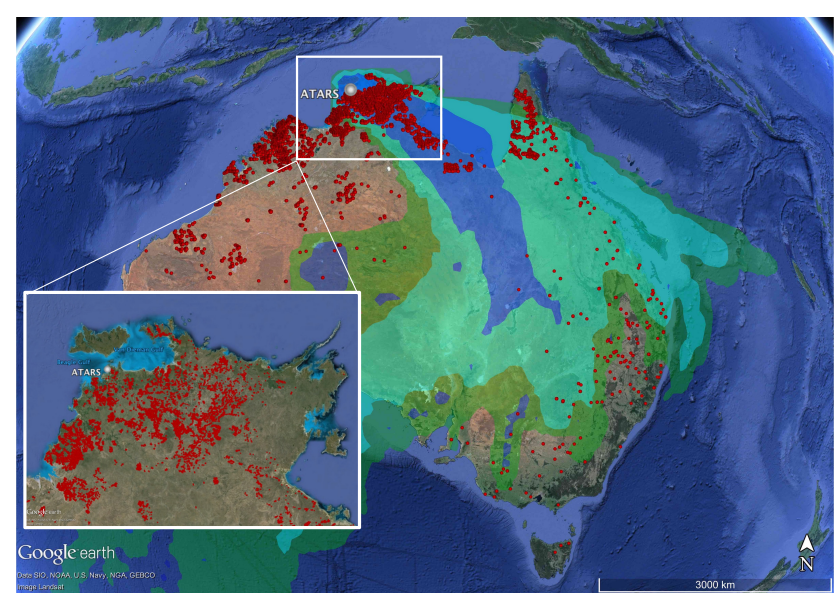

Figure 1. All satellite-detected fires with $>50 \%$ detection confidence in June 2014 in Australia. Trajectory densities are shown as shaded regions (blue: $>10 \%$ of all data; cyan: $>1 \%$ of all data; green: $>0.1 \%$ of all data).

Table 2. The start and end dates for the four identified biomass burning periods (BBP1, BBP2, BBP3 and BBP4) and the coastal period (CP).

\begin{tabular}{lrr}
\hline Period & $\begin{array}{r}\text { Start date } \\
(\mathrm{mm} / \mathrm{dd} / \mathrm{yy} \text { hh:mm })\end{array}$ & $\begin{array}{r}\text { End date } \\
(\mathrm{mm} / \mathrm{dd} / \mathrm{yy} \mathrm{hh:mm})\end{array}$ \\
\hline BBP1 & $05 / 30 / 14$ 00:00 & $05 / 31 / 1423: 59$ \\
BBP2 & $06 / 06 / 1400: 00$ & $06 / 12 / 1423: 59$ \\
BBP3 & $06 / 14 / 1400: 00$ & $06 / 17 / 1423: 59$ \\
CP & $06 / 19 / 1412: 00$ & $06 / 22 / 1423: 59$ \\
BBP4 & $06 / 23 / 1400: 00$ & $06 / 28 / 1423: 59$ \\
\hline
\end{tabular}

burning-related periods (BBP1, BBP2, BBP3 and BBP4) and a "coastal" period (CP). The dates for these periods are displayed in Table 2.

The number of detected fires on each day within 10, 20, 50,100 and $200 \mathrm{~km}$ of the sampling location was determined (see Fig. 2). Several fires within $10 \mathrm{~km}$ were detected on 30 May (BBP1), 9 and 10 June (BBP2) and 25 and 26 June (BBP4). BBP1, BBP2 and BBP4 were also associated with the highest concentrations of most of the measured gaseous (Fig. 3) and aerosol species (Fig. 4). The periods between 12 and 23 June (BBP3 and CP) had very few detected fires within $50 \mathrm{~km}$ of the station, corresponding to smaller gaseous and aerosol concentrations.

Most of the gaseous and aerosol time series show a pronounced diurnal trend, with higher concentrations typically observed during the night (see Figs. 5 and and S2). This is likely due to a combination of variations in fire locations, time of burns, and changes in the boundary layer height or wind velocity. The diurnal trends of radon concentrations, temperature, wind speed, wind direction and greenhouse gases for each of the BBPs and the CP are displayed in Fig. 5. The radon concentrations provide further information regard- 


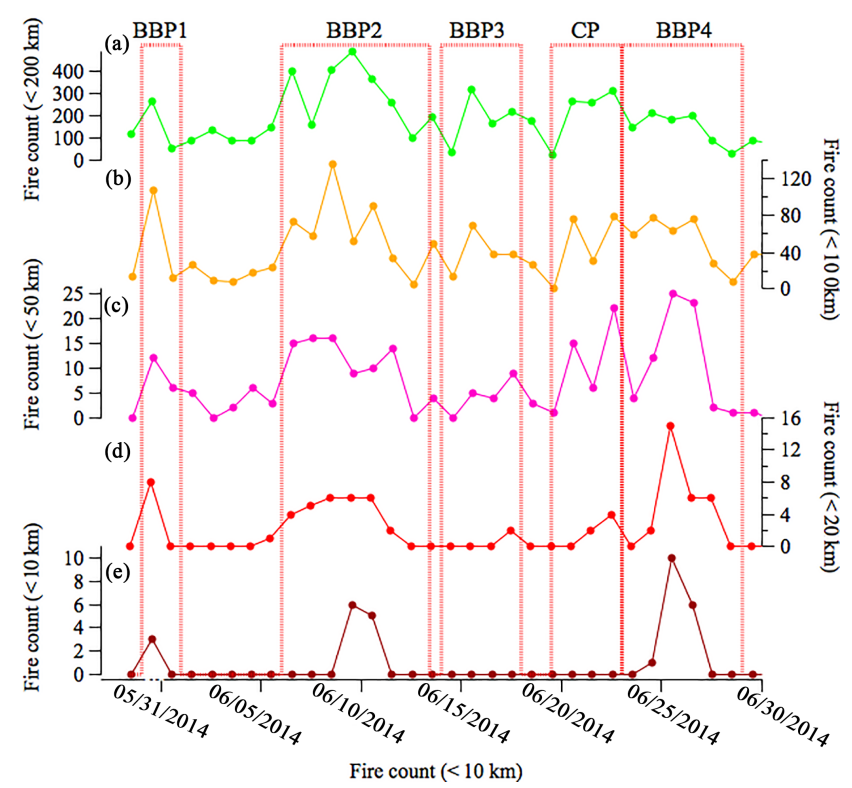

Figure 2. The number of hotspots observed each day within (a) $200 \mathrm{~km}$, (b) $100 \mathrm{~km}$, (c) $50 \mathrm{~km}$, (d) $20 \mathrm{~km}$ and (e) $10 \mathrm{~km}$ of ATARS, as detected by the MODIS and VIIRS sensors on the Terra and Aqua satellites.

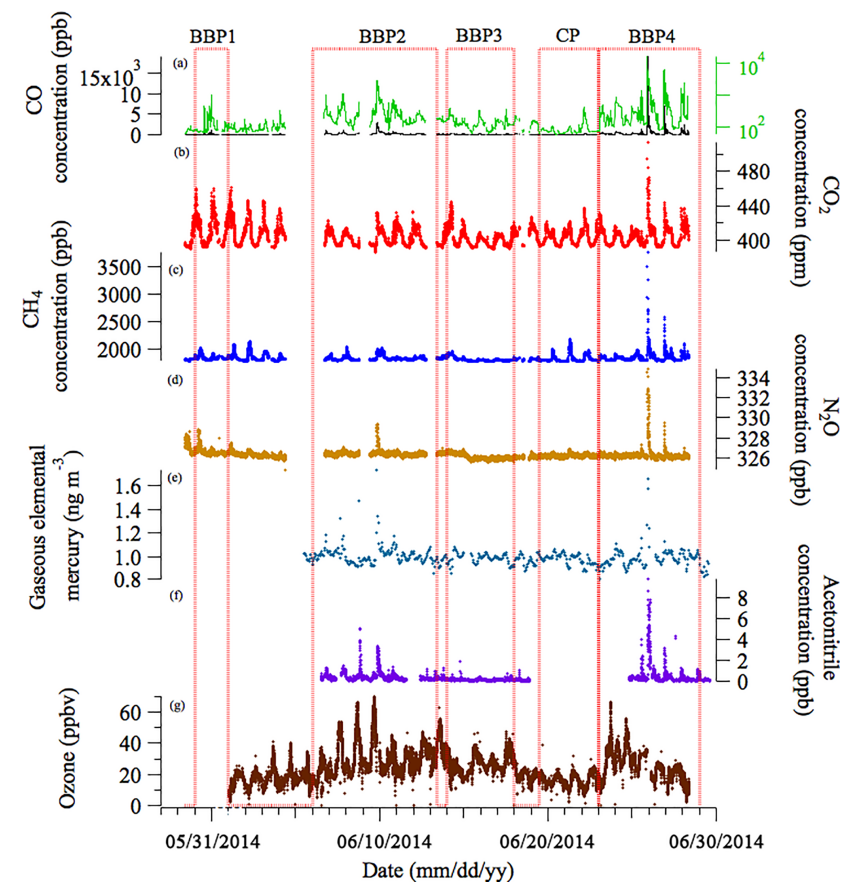

Figure 3. The time series of the major measured gaseous species during the SAFIRED campaign: (a) carbon monoxide, (b) carbon dioxide, (c) methane, (d) nitrous oxide, (e) gaseous elemental mercury, (f) acetonitrile and (g) ozone. The biomass burning and coastal periods are indicated by the red dotted lines. All parts-per notation refers to mole fractions unless otherwise indicated. The date and time is local time. ing the regional air mass origins and the degree of contact with the land surface and give insight into the boundary layer. Sharp decreases in the radon concentrations were observed after 09:00 local time and did not increase until after sunset at approximately 18:00 for all periods (Fig. 5a), suggesting a pronounced diurnal variation in the boundary layer height. Furthermore, radon concentrations were consistently lower during the $\mathrm{CP}$ than the $\mathrm{BB}$ periods, suggesting less terrestrial influence than the rest of the sampling period. The HYSPLIT air mass back trajectory for the CP originated along the east coast of Australia and passing over little land before arriving at the station. Figure 5d supports this, showing predominately easterly and north-easterly winds during the night and day, respectively. The diurnal variations during the $\mathrm{BB}$ periods were more pronounced. The winds during these periods were predominately south-easterly during the night and morning, turning easterly during the afternoon before reverting at approximately 20:00 local time. The HYSPLIT air mass back trajectories for the BB periods indicated terrestrial origins, with air masses passing predominately over the savannah region of northern Australia where the fires occurred.

With numerous fires occurring across the region and the limitations of once-per-day satellite flyovers and stationary measurements, it can be difficult to identify the exact source of these elevated signals. Nonetheless, it is possible to link detected plumes with fires given back-trajectory analysis. The elevated signals during BBP1 were likely a result of several fires that were burning and observed on 30 May at 14:00 local time approximately 2 and $10 \mathrm{~km}$ from ATARS during the day. While the elevated signals were observed later in the evening, it is likely that they were due to a continuation or evolution of those fires. Some of the most intense signals of the campaign were observed during BBP2, with numerous close (within $50 \mathrm{~km}$ ) and distant (within $200 \mathrm{~km}$ ) detected. Due to the limitations of the once-per-day satellite fly-by, it was only possible to link one of the observed plumes to a source during this period. A large event observed on the evening of 9 June was likely due to a cluster of fires detected approximately $5 \mathrm{~km}$ south-east of ATARS. Only one fire within $20 \mathrm{~km}$ of ATARS was observed via satellite during BBP3 on 17 June but this was not associated with any significant increase in gaseous or aerosol concentrations. Several fires were also observed between 20 and $50 \mathrm{~km}$ from the station. One close fire was also observed during CP; however, wind directions during this period were typically northeasterly and concentrations were therefore much lower. Fiveday HYSPLIT trajectories also show that air mass during the $\mathrm{CP}$ originated along the east coast of Australia before travelling towards the sampling station with very little terrestrial influence.

For a portion of BBP4, fires were burning within several kilometres of ATARS and several plumes were easily observed from the station. The signals from these plumes are shown in Fig. 6. The observed enhancements between 12:30 and 15:00 on 25 June during BBP4 were a result of grass fires 


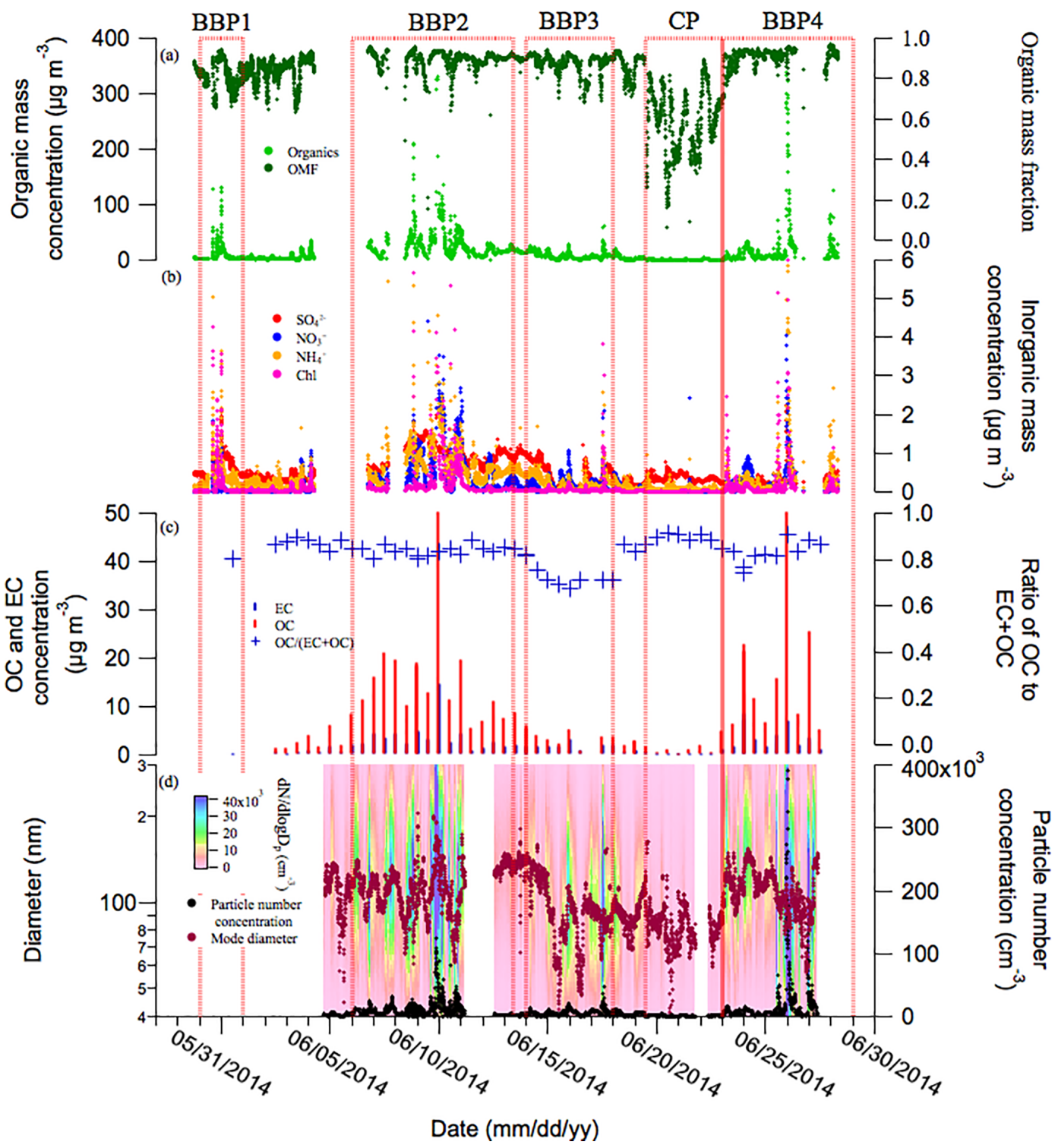

Figure 4. The times series of the major aerosol properties during the SAFIRED campaign: (a) the non-refractory $\mathrm{PM}_{1}$ organic mass concentration (left) and organic mass fraction (right), (b) the inorganic non-refractory $\mathrm{PM}_{1}$ mass concentrations, (c) the $12 \mathrm{~h}$ filter OC and EC PM mass concentrations (left) and the ratio of OC to OC+EC (right), (d) the particle size distributions and particle size mode (left) and the total particle number concentration (right) at ATARS. The date and time is local time.

burning approximately $2 \mathrm{~km}$ south-east from the station. During this event, the wind direction was highly variable, changing between 140 and $80^{\circ}$ true bearing (TB) multiple times. As a result, the sampling changed from measuring the air mass with and without the plume from this fire, which led to sharp increases and decreases in biomass burning-related signals. Visually, the fire area and extent of the plume was larger at 16:00 than earlier; however, the wind direction changed to north-easterly, which directed the plume away from the station. From 16:00 until 22:00, the wind direction was stable at approximately $50^{\circ} \mathrm{TB}$. At 22:00, the wind direction rapidly changed to directly south and the largest enhance- ments for the whole campaign were observed until approximately $02: 00$ on 26 June. It is very likely that these signals were a result of a continuation and evolution of these fires as the night progressed. Portions of a $\sim 0.25 \mathrm{~km}^{2}$ grassland field within $500 \mathrm{~m}$ directly south of ATARS were observed to be burned upon arrival at the station on the morning of 26 June and we speculate that the burning of this field contributed to the large enhancements in measured biomass burning emissions. The emissions during this portion of BBP4 are likely to be the most representative of fresh biomass burning smoke during the SAFIRED campaign. Significant ozone enhancements over $80 \mathrm{ppb}$ were observed during this event, although 

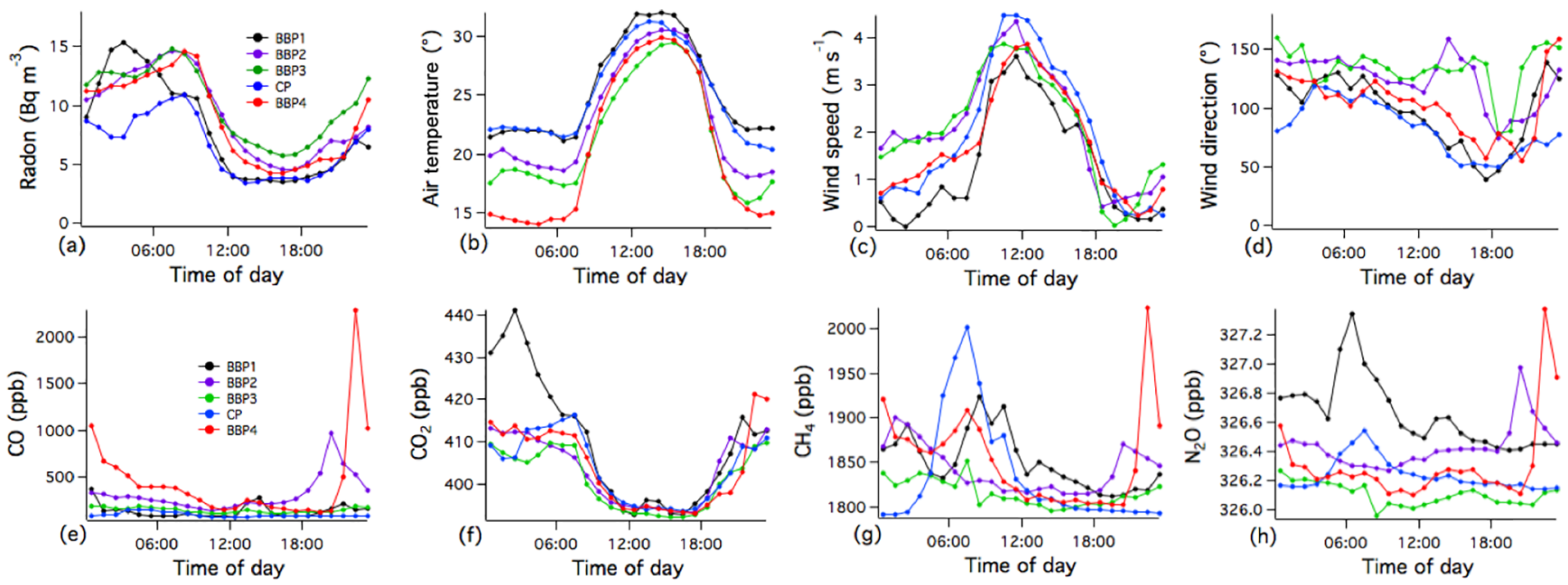

Figure 5. Mean hourly diurnal (a) radon, (b) wind speed, (c) wind direction (d) dew point temperature (e) $\mathrm{CO}_{2}(\mathbf{c}) \mathrm{CO}_{2}$, (d) $\mathrm{CH}_{4}$, and (e) $\mathrm{N}_{2} \mathrm{O}$ at ATARS, separated into different biomass burning periods (BBP) and a coastal period (CP). All parts-per notation refers to mole fractions.

this was likely result of a cross-contamination due to concurrently high concentrations of UV-absorbing organic compounds in the gaseous phase. This enhancement would only be possible with significant photochemical processing, which is very unlikely considering the time of the event, the visual evidence of close fires, and the large concentrations observed.

Based on the elevated concentrations of biomass burning related gaseous and aerosol species, detection of close fires and the air mass back-trajectory analysis during portions of BBP1, BBP2 and BBP4, these periods are likely associated with fresh biomass burning smoke from nearby fires. With smaller concentrations and more distant observed fires, the signals observed during BBP 3 are possibly more characteristic of aged biomass burning smoke. The influence of biomass burning during $\mathrm{CP}$ was much smaller than the rest of the campaign. Investigating the relationship between toluene and acetonitrile, two NMOCs emitted from biomass burning, can provide further information on the aging of $\mathrm{BB}$ emissions. Toluene is much shorter lived than acetonitrile as it readily reacts in the presence of the $\mathrm{OH}$ radical. Assuming a consistent emission ratio of these two NMOCs from fires in this region, the ratio of toluene/acetonitrile thereby provides a proxy for photochemical age. Unfortunately, the PTR-MS which measures these species was not operational during BBP1 and CP. The diurnal trends for the toluene and acetonitrile concentrations and the toluene/acetonitrile ratio is shown in Fig. 7 for BBP2, BBP3 and BBP4. The toluene/acetonitrile ratio was highest during the night, indicating more photochemically aged smoke throughout the day. Interestingly, while the toluene and acetonitrile concentrations were consistently higher during BBP2 and BBP4 than BBP3, the toluene/acetonitrile ratio was of the same magnitude and followed the same trend. It is therefore plau- sible that, while there were no large enhancements in concentrations during BBP 3 and there were few fires detected closeby during the daytime satellite flyovers, there were smallscale burns during the night that were close enough for the emissions to reach the sampling site. This observation highlights the limitation of using satellite hotspot detection in fully understanding the aging processes of biomass burning emissions.

Particle size distributions were unimodal for the majority of the sampling period with a mode of approximately $100 \mathrm{~nm}$ on average (see Fig. 8). The SMPS was not operational during BBP1. Although the shape of the BBP4 size distribution was similar to the campaign average, concentrations were much higher and a result of close fires. BBP2 had a slightly larger size distribution centred on $110 \mathrm{~nm}$. The size distribution during BBP3 was slightly smaller than the campaign average and BBP2 and BBP4, with a mode centred on $\sim 95 \mathrm{~nm}$. Furthermore, the diurnal trends of the BBA mode diameter during BBP2, BBP3 and BBP4 and $\mathrm{CP}$ all showed a clear maximum during the night (see Fig. S2d). The diurnal trends of the toluene/acetonitrile ratios (Fig. 7c) as well as the ratio of oxygenated organic aerosol to total organics (see Fig. S2c) suggest that the larger night time particle sizes are more associated with fresh biomass burning. The contrast between these size distributions could be a result of atmospheric aging and dilution in which organic mass condenses onto or evaporates from the particle. Variations in fuel load or burning conditions could also contribute to this difference. The size and concentration of particles during $\mathrm{CP}$ were much smaller than the rest of the campaign. There were two periods during $\mathrm{CP}$ where a bimodal size distribution was observed: one from approximately 15:00 until midnight on 19 June and the other between 14:00 and 18:00 on 20 June. The size distributions for both of these periods had a mode 

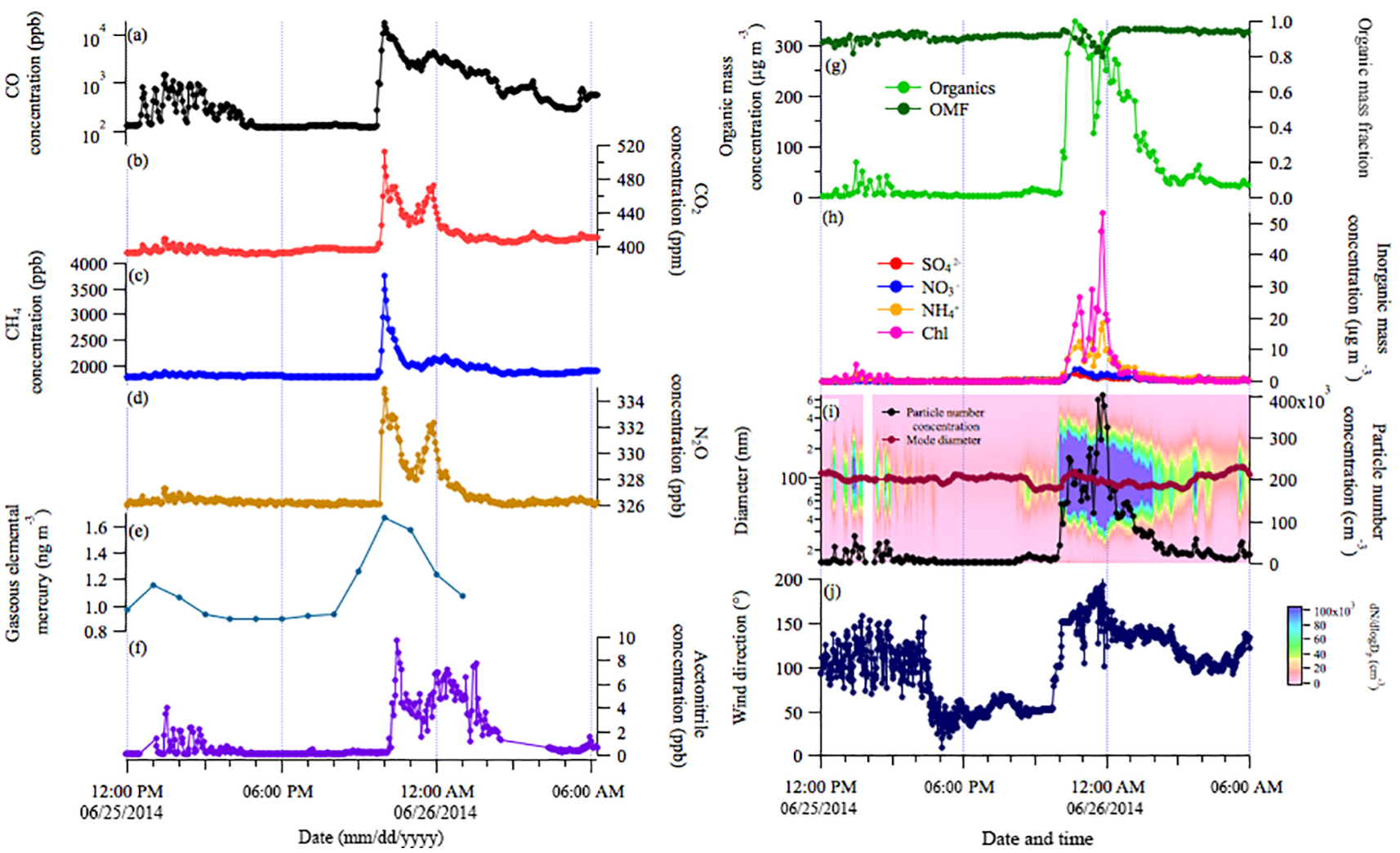

Figure 6. The major gas and aerosol concentrations measured during two biomass burning events within 1 km of ATARS during BBP4. Panels (a-g) and (h-k) are as per Figs. 3 and 4, respectively. All parts-per notation refers to mole fractions unless otherwise indicated. The date and time are local time.
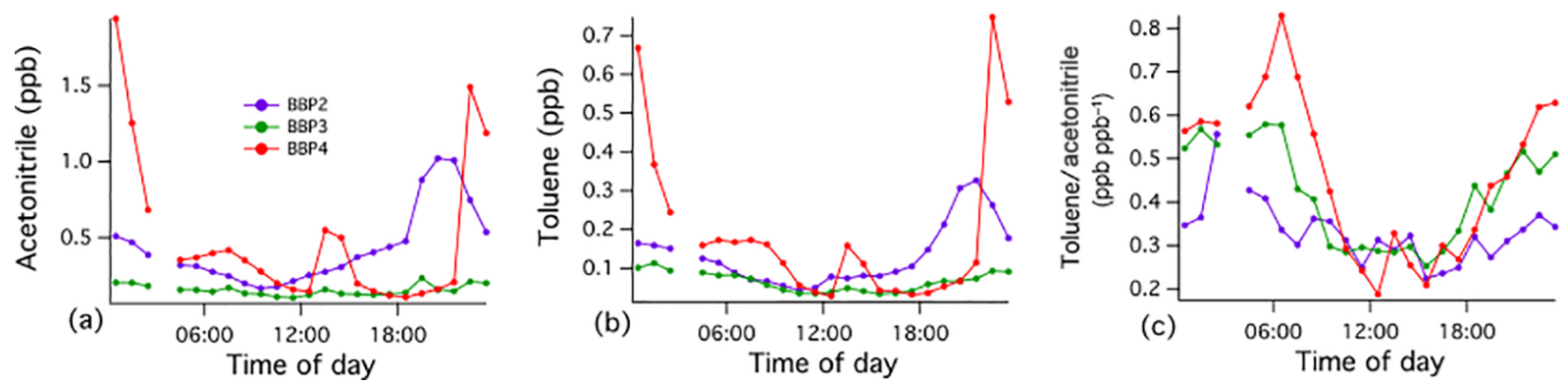

Figure 7. Mean hourly diurnal (a) acetonitrile concentration, (b) toluene concentration, and (c) toluene/acetonitrile ratio, separated into different biomass burning periods (BBP). All parts-per notation refers to mole fractions.

at approximately $20 \mathrm{~nm}$ and another at approximately $85 \mathrm{~nm}$. Submicron sulfates made up to $32 \%$ of the total submicron non-refractory mass concentrations, as reported by the cToFAMS from the period of midday on 19 June until midnight on 22 June, whereas the average sulfate contribution for the rest of the campaign was approximately $8 \%$. The low radon values, small particle concentrations, bimodal size distributions and significant contributions of sulfate during this period also suggest very little biomass burning signal and a more marine-like aerosol. No particle nucleation events were observed over the entire sampling period (see Fig. S3). This is likely due to the elevated particle concentrations acting as a condensation sink.

Over the campaign, organics dominated the non-refractory submicron aerosol mass contributing, on average, $90 \%$ of the total mass. Sulfate, nitrates, ammonium and chloride species contributed the rest of this mass, with the largest contributions from sulfate and ammonium. Sulfate contributions were very significant during the coastal period, contributing up to $32 \%$ of the total mass. Although chlorides contributed the least to the total mass on average, during clear biomass burning events where sharp increases in $\mathrm{CO}$ and organics were 


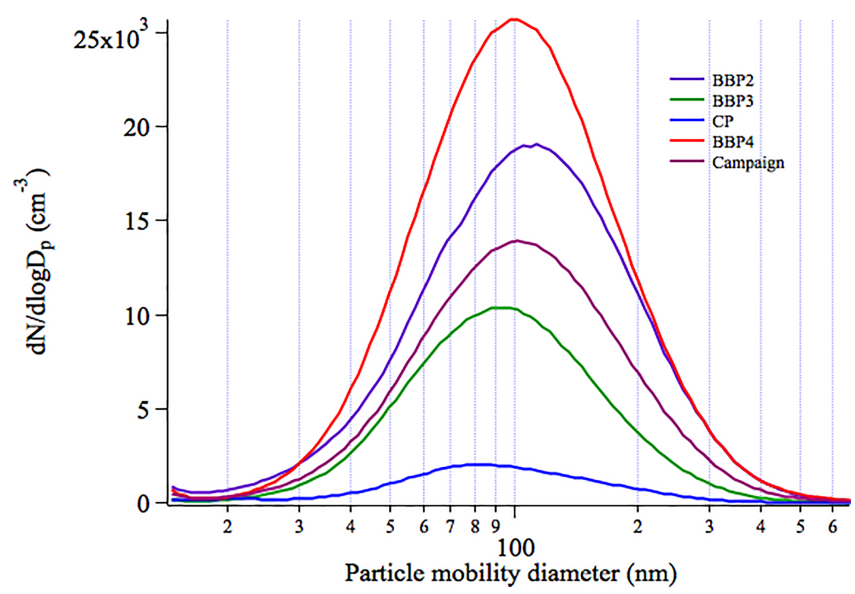

Figure 8. The average number size distribution during BBP2, $\mathrm{BBP} 3, \mathrm{BBP} 4, \mathrm{CP}$ and the campaign average.

Table 3. A list of currently published companion studies undertaken during SAFIRED.

\begin{tabular}{|c|c|}
\hline Reference & Title \\
\hline Winton et al. (2016) & $\begin{array}{l}\text { Dry season aerosol iron solubility } \\
\text { in tropical northern Australia }\end{array}$ \\
\hline Wang et al. (2017) & $\begin{array}{l}\text { Emissions of selected semivolatile organic } \\
\text { chemicals from forest and savannah fires }\end{array}$ \\
\hline Milic et al. (2017) & $\begin{array}{l}\text { Biomass burning and biogenic aerosols in } \\
\text { northern Australia during the SAFIRED campaign }\end{array}$ \\
\hline Mallet et al. (2017) & $\begin{array}{l}\text { Composition, size and cloud condensation nuclei } \\
\text { activity of biomass burning aerosol } \\
\text { from northern Australian savannah fires }\end{array}$ \\
\hline Desservattaz et al. (2017) & $\begin{array}{l}\text { Emission factors of trace gases and particles } \\
\text { from tropical savanna fires in Australia }\end{array}$ \\
\hline Howard et al. (2017) & $\begin{array}{l}\text { Atmospheric mercury in the southern hemisphere } \\
\text { tropics: seasonal and diurnal variations and } \\
\text { influence of inter-hemispheric transport }\end{array}$ \\
\hline
\end{tabular}

observed, chlorides made up the largest component of inorganic aerosol. Organic carbon made up approximately 80 to $90 \%$ of the total carbon (organic carbon + elemental carbon) $\mathrm{PM}_{1}$ mass during the campaign, with the exception of BBP3, when this dropped to $70 \%$. Whether these observations were a result of burn conditions or aging processes (i.e. evaporation of organic compounds from the aerosol phase) is unclear.

\section{Outcomes of SAFIRED}

The overall aim of this study was to investigate the characteristics of $\mathrm{BB}$ emissions in the tropical savannah region of northern Australia during the early dry season. For many gaseous and aerosol species, elevated signals were observed for much of the month-long sampling period due to the high frequency of fires. Further analysis of these species can provide more insight into the impact of these fires on the regional atmosphere. Table 2 displays a summary of companion studies undertaken within the SAFIRED campaign.

\subsection{Emission factors and gaseous species loadings}

Desservettaz et al. (2017) identified individual plumes with high signals during SAFIRED in order to determine emission factors of $\mathrm{CO}_{2}, \mathrm{CO}, \mathrm{CH}_{4}$, and $\mathrm{N}_{2} \mathrm{O}$, as well as GEM, Aitken- and accumulation-mode aerosols, and submicron non-refractory particle species (organics, sulfates, nitrates, ammonium and chlorides). Seasonal emission factors for the major greenhouse gases are important for national greenhouse gas inventories and in understanding the impact of savannah fires. Furthermore, these results will be the first set of emission factors for aerosol particles from savannah fires in Australia, with early results suggesting higher factors than those observed from African and South American savannah fires. Emission factors were mostly found to be dependent on the combustion conditions (using the modified combustion efficiency as a proxy) of the fires.

Wang et al. (2017) investigated 13 major PAH compounds in both the gaseous and aerosol phase during the SAFIRED campaign and estimated their emission factors from savannah fires, as well as from subtropical eucalypt forest fires. Concentrations of these PAHs varied from $\sim 1$ to over $15 \mathrm{ng} \mathrm{m}^{-3}$ within different BB periods and the emission factor for savannah fires for $\sum_{13}$ PAHs were estimated to be $1600 \pm 110 \mu \mathrm{g} \mathrm{kg}^{-1}$ In the gas phase, three- and four-ring compounds typically contributed $\sim 90 \%$ to the sum concentrations whereas the particle-associated PAHs were dominated by five- and six-ring compounds ( $>80 \%)$. Measured PAH concentrations were significantly higher during BBP2 and BBP4. During these periods, concentrations of BaP exceeded the monitoring investigation level for atmospheric $\mathrm{BaP}\left(0.30 \mathrm{ng} \mathrm{m}^{-3}\right)$ in Australia (National Environment Protection Council Service Corporation, 2011) by up to $200 \%$.

Biomass burning produces significant amounts of semivolatile NMOC, which can be difficult to quantify and identify with current measurement techniques. However recent studies have shown that including semi-volatile NMOC chemistry in models improves the agreement between the modelled and observed organic aerosol (Alvarado et al., 2015; Konovalov et al., 2015) and ozone (Alvarado et al., 2015). High-quality NMOC emission factors are crucial for models to assess the impact of biomass burning plumes on air quality and climate. Future analyses will be undertaken on the SAFIRED data to quantify emission factors for various NMOCs.

SAFIRED represents the first measurements of atmospheric mercury undertaken in the tropical region of the Australian continent. The mean observed GEM concentration over the study period was $0.99 \pm 0.09 \mathrm{ng} \mathrm{m}^{-3}$, similar to the average over that month $\left(0.96 \mathrm{ng} \mathrm{m}^{-3}\right)$ for five other Southern Hemisphere sites and slightly lower than the average $\left(1.15 \mathrm{ng} \mathrm{m}^{-3}\right)$ for five tropical sites (Sprovieri et al., 2016). Mean GOM and PBM concentrations were $11 \pm 5$ and $6 \pm 3 \mathrm{pg} \mathrm{m}^{-3}$ respectively, representing $0.6-3.4 \%$ of total observed atmospheric mercury. During periods of pro- 
nounced trace gas and aerosol concentrations during the campaign, spikes in GEM concentrations were also observed, though there were no significant increases in GOM or PBM. Emission ratios calculated during the campaign were 2 orders of magnitude higher than those reported by Andreae and Merlet (2001). Future outcomes from the SAFIRED campaign will focus on the use of micrometeorological techniques and the passive tracer radon to quantify delivery of atmospheric mercury to tropical savannah ecosystems. ATARS also now serves as an additional site measuring continuous GEM as part of the Global Mercury Observation System (GMOS), one of only two tropical observing sites in the eastern hemisphere and the third such site located in Australia. A discussion of the seasonal and diurnal variations of atmospheric mercury at the ATARS site can be found in Howard et al. (2017).

\subsection{Biomass burning aerosol chemistry}

Milic et al. (2017) provided further analysis into the aerosol chemical composition to elucidate the aging of early dry season biomass burning emissions. Fractional analysis (e.g. $f 44$ and $f 60$, the fraction of $m / z 44$ and $m / z 60$ to all organic masses, indicated oxygenation and BB sources, respectively) and factor analysis using positive matrix factorisation (PMF) of cToF-AMS data were investigated over the entire sampling period. Outside of the periods of significant influence from BB events, three PMF-resolved organic aerosol factors were identified. A BB organic aerosol factor was found to comprise $24 \%$ of the submicron non-refractory organic mass, with an oxygenated organic aerosol factor and a biogenic isoprene-related secondary organic aerosol factor comprising 47 and $29 \%$, respectively. These results indicate the significant influence of fresh and aged BB on aerosol composition in the early dry season. The emission of precursors from fires is likely responsible for some of the secondary organic aerosol formation.

The water uptake of aerosols during SAFIRED was further investigated in Mallet et al. (2017) to identify the influence of early dry season BB in this region on cloud formation. The concentrations of cloud condensation nuclei at a constant supersaturation of $0.5 \%$ were typically of the order of $2000 \mathrm{~cm}^{-3}$ and reached well over $10000 \mathrm{~cm}^{-3}$ during intense BB events. Variations in the ratio of aerosol particles activating cloud droplets showed a distinct diurnal trend, with an activation ratio of $40 \% \pm 20 \%$ during the night and $60 \% \pm 20 \%$ during the day. The particle size distribution and the hygroscopicity of the particles were found to significantly influence this activation ratio. Particles were generally extremely hydrophobic, particularly during the night and during the $\mathrm{BB}$ periods shown in this paper. Modelling CCN concentrations using the size distributions of aerosols and typical continental and terrestrial values of hygroscopicities yielded significant overpredictions of more than $200 \%$, highlighting the need to include more regional parameterisations of aerosol composition and hygroscopicity.

Furthermore the fractional solubility of aerosol iron and other trace metals during SAFIRED were investigated in Winton et al. (2016). The fractional iron solubility is an important variable determining iron availability for biological uptake in the ocean. On a global scale, the large variability in the observed fractional iron solubility results, in part, from a mixture of different aerosol sources. Estimates of fractional iron solubility from fire combustion (1-60\%) are thought to be greater than those originating from mineral dust (1-2\%; Chuang et al., 2005; Guieu et al., 2005; Sedwick et al., 2007) and may vary in relation to biomass and fire characteristics as well as that of the underlying terrain (Paris et al., 2010; Ito, 2011). Iron associated with BB may provide information with respect to BB inputs of iron to the ocean (Giglio et al., 2013; e.g. Meyer et al., 2008). ATARS provides an ideal location to further investigate BB-derived fractional iron solubility at the source. The results from this study can be found in Winton et al. (2016) and show that soluble iron concentrations from BB sources are significantly higher than those observed in Southern Ocean baseline air masses from the Cape Grim Baseline Air Pollution Station, Tasmania, Australia (Winton et al., 2015). Aerosol iron at SAFIRED was a mixture of fresh BB, mineral dust, sea spray and industrial pollution sources. The fractional iron solubility (2-12\%) was relatively high throughout the campaign and the variability was related to the mixing and enhancement of mineral dust iron solubility with BB species.

\section{Conclusions and future outlook}

Biomass burning was found to significantly influence the surface atmospheric composition during the 2014 early dry season in north Australia. Over 28000 fires were detected via satellite retrieval during the sampling period. Several periods were identified when fires within $20 \mathrm{~km}$ of the research station resulted in significant enhancements of greenhouse gases, non-methane gaseous organic compounds, gaseous elemental mercury and polycyclic aromatic hydrocarbons and aerosol loadings. Much of the $\mathrm{PM}_{1}$ mass was comprised of organic material. The aerosol particle number size distributions were typically unimodal and centred around $100 \mathrm{~nm}$, which is smaller than BBA observed in other regions. The analysis of the time series of these measured quantities has so far allowed the quantification of savannah fire emission factors for these aerosol and gaseous species and has provided and understanding of the aerosol aging, water uptake and solubility in this region.

While the specific outcomes of the SAFIRED campaign are reviewed in the previous section, the general importance of this study can be discussed in a greater context. This is the first large-scale collaborative project undertaken in this region and draws on the resources and expertise of most of 
Australia's research institutes focused on atmosphere chemistry and composition. Large-scale, multidisciplinary measurement campaigns in the tropics, such as SAFIRED, are needed to make distinctions between different types of fires in different regions to reduce uncertainties in global climate models (Keywood et al., 2013). This need has been recognised with the formation of global collaborative initiatives promoting interdisciplinary collaboration in biomass burning research (Kaiser and Keywood, 2015). As the world moves towards a warmer climate, it is plausible that the frequency and intensity of biomass burning will increase, and these emissions will become an increasingly important source of trace gases and aerosols to the atmosphere.

SAFIRED lays the foundation for future measurements at ATARS that could make measurements throughout the whole dry season and on a more long-term scale. Future work in this region should focus on (1) the detailed characterisation of individual fires and their emissions, (2) biomass burning emissions throughout the late dry season and (3) the vertical and horizontal transport of biomass burning emissions in this region. With well-established emission factors, a concentrated effort should be made to link modelled aerosol gaseous and aerosol loadings with in situ and remote sensing measurements. This should be done not just at the surface but also throughout the boundary layer as well as over the waters north of Australia. Furthermore, a further investigation of the radiative influence of the gaseous and aerosol species should be done for this region.

Data availability. All data are available upon request from the corresponding authors (Branka Miljevic, b.miljevic@qut.edu.au; Melita D. Keywood; melita.keywood@csiro.au).

\section{The Supplement related to this article is available online at https://doi.org/10.5194/acp-17-13681-2017- supplement.}

Author contributions. MDM wrote the manuscript. MDK organised and led the campaign. All authors contributed to the organisation of the campaign and/or installed or operated instrumentation during the sampling period. All authors contributed to data analysis and/or interpretation. All authors reviewed the manuscript.

Competing interests. The authors declare that they have no conflict of interest.

Acknowledgements. The majority of the campaign was internally funded. The input of Queensland University of Technology was supported by the Australian Research Council Discovery (grant DP120100126). The work on aerosol iron solubility was supported by Curtin University (RES-SE-DAP_AW-47679-1), the University of Tasmania (B0019024) and the Australian Research Council (grant FT130100037).

Edited by: Jason Surratt

Reviewed by: three anonymous referees

\section{References}

Akagi, S. K., Craven, J. S., Taylor, J. W., McMeeking, G. R., Yokelson, R. J., Burling, I. R., Urbanski, S. P., Wold, C. E., Seinfeld, J. H., Coe, H., Alvarado, M. J., and Weise, D. R.: Evolution of trace gases and particles emitted by a chaparral fire in California, Atmos. Chem. Phys., 12, 1397-1421, https://doi.org/10.5194/acp12-1397-2012, 2012.

Alvarado, M. J., Lonsdale, C. R., Yokelson, R. J., Akagi, S. K., Coe, H., Craven, J. S., Fischer, E. V., McMeeking, G. R., Seinfeld, J. H., Soni, T., Taylor, J. W., Weise, D. R., and Wold, C. E.: Investigating the links between ozone and organic aerosol chemistry in a biomass burning plume from a prescribed fire in California chaparral, Atmos. Chem. Phys., 15, 6667-6688, https://doi.org/10.5194/acp-15-6667-2015, 2015.

Andersen, A. N., Cook, G. D., Corbett, L. K., Douglas, M. M., Eager, R. W., Russell-Smith, J., Setterfield, S. A., Williams, R. J., and Woinarski, J. C.: Fire frequency and biodiversity conservation in Australian tropical savannas: implications from the Kapalga fire experiment, Aust. Ecol., 30, 155-167, 2005.

Andreae, M. O. and Merlet, P.: Emission of trace gases and aerosols from biomass burning, Global Biogeochem. Cy., 15, 955-966, 2001.

Bindoff, N. L., Stott, P. A., AchutaRao, K. M., Allen, M. R., Gillett, N., Gutzler, D., Hansingo, K., Hegerl, G., Hu, Y., Jain, S., Mokhov, I. I., Overland, J., Perlwitz, J., Sebbari, R., and Zhang, X.: Detection and Attribution of Climate Change: from Global to Regional, in: Climate Change 2013: The Physical Science Basis. Contribution of Working Group I to the Fifth Assessment Report of the Intergovernmental Panel on Climate Change, edited by: Stocker, T. F., Qin, D., Plattner, G.-K., Tignor, M., Allen, S. K., Boschung, J., Nauels, A., Xia, Y., Bex, V., and Midgley, P. M., Cambridge University Press, Cambridge, United Kingdom and New York, NY, USA, 867-952, 2013.

Chambers, S. D., Hong, S.-B., Williams, A. G., Crawford, J., Griffiths, A. D., and Park, S.-J.: Characterising terrestrial influences on Antarctic air masses using Radon-222 measurements at King George Island, Atmos. Chem. Phys., 14, 9903-9916, https://doi.org/10.5194/acp-14-9903-2014, 2014.

Cheng, M., Galbally, I., Molloy, S., Selleck, P., Keywood, M., Lawson, S., Powell, J., Gillett, R., and Dunne, E.: Factors controlling volatile organic compounds in dwellings in Melbourne, Australia, Indoor air, 26, 219-230, https://doi.org/10.1111/ina.12201, 2016.

Chow, J. C., Watson, J. G., Chen, L. W. A., Chang, M. C. O., Robinson, N. F., Trimble, D., and Kohl, S.: The IMPROVE-A temperature protocol for thermal/optical carbon analysis: maintaining consistency with a long-term database, J. Air Waste Manage., 57, 1014-1023, 2007.

Chuang, P. Y., Duvall, R. M., Shafer, M. M., and Schauer, J. J.: The origin of water soluble particulate iron in the 
Asian atmospheric outflow, Geophys. Res. Lett., 32, L07813, https://doi.org/10.1029/2004GL021946, 2005.

Crutzen, P. J. and Andreae, M. O.: Biomass burning in the tropics: Impact on atmospheric chemistry and biogeochemical cycles, Science, 250, 1669-1678, 1990.

Desservettaz, M., Paton-Walsh, C., Griffith, D. W., Kettlewell, G., Keywood, M. D., Vanderschoot, M. V., Ward, J., Mallet, M. D., Milic, A., and Miljevic, B.: Emission factors of trace gases and particles from tropical savanna fires in Australia, J. Geophys. Res.-Atmos., https://doi.org/10.1002/2016JD025925, 2017.

Draxler, R. R. and Rolph, G. D.: HYSPLIT (HYbrid Single-Particle Lagrangian Integrated Trajectory) Model access via NOAA ARL READY Website, available at: http://ready.arl.noaa.gov/ HYSPLIT.php (last access: 5 April 2016), NOAA Air Resources Laboratory, Silver Spring, MD, 2011.

Drewnick, F., Hings, S. S., DeCarlo, P., Jayne, J. T., Gonin, M., Fuhrer, K., Weimer, S., Jimenez, J. L., Demerjian, K. L., and Borrmann, S.: A new time-of-flight aerosol mass spectrometer (TOF-AMS)-Instrument description and first field deployment, Aerosol Sci. Technol., 39, 637-658, https://doi.org/10.1080/02786820500182040, 2005.

Du, H., Kong, L., Cheng, T., Chen, J., Du, J., Li, L., Xia, X., Leng, C., and Huang, G.: Insights into summertime haze pollution events over Shanghai based on online water-soluble ionic composition of aerosols, Atmos. Environ., 45, 5131-5137, 2011.

Dunne, E., Galbally, I. E., Cheng, M., Selleck, P., Molloy, S. B., and Lawson, S. J.: Comparison of VOC measurements made by PTR-MS, Adsorbent Tube/GC-FID-MS and DNPHderivatization/HPLC during the Sydney Particle Study, 2012: a contribution to the assessment of uncertainty in current atmospheric VOC measurements, Atmos. Meas. Tech. Discuss., https://doi.org/10.5194/amt-2016-349, in review, 2017.

Edwards, G. C., Rasmussen, P. E., Schroeder, W. H., Wallace, D. M., Halfpenny-Mitchell, L., Dias, G. M., Kemp, R. J., and Ausma, S.: Development and evaluation of a sampling system to determine gaseous Mercury fluxes using an aerodynamic micrometeorological gradient method, J. Geophys. Res.-Atmos., 110, https://doi.org/10.1029/2004JD005187, 2005.

Fedele, R. M.: Observations of Australian Cloud Condensation Nuclei (CCN), RMIT University, 2015.

Ferek, R. J., Reid, J. S., Hobbs, P. V., Blake, D. R., and Liousse, C.: Emission factors of hydrocarbons, halocarbons, trace gases and particles from biomass burning in Brazil, J. Geophys. Res., 103, 107-132, 1998.

Galbally, I. E., Lawson, S. J., Weeks, I. A., Bentley, S. T., Gillett, R. W., Meyer, M., and Goldstein, A. H.: Volatile organic compounds in marine air at Cape Grim, Australia, Environ. Chem., 4, 178182, https://doi.org/10.1071/EN07024, 2007.

Giglio, L., Randerson, J. T., and Werf, G. R.: Analysis of daily, monthly, and annual burned area using the fourth-generation global fire emissions database (GFED4), J. Geophys. Res.Biogeo., 118, 317-328, 2013.

Govender, N., Trollope, W. S., and Van Wilgen, B. W.: The effect of fire season, fire frequency, rainfall and management on fire intensity in savanna vegetation in South Africa, J. Appl. Ecol., 43, 748-758, 2006.

Griffith, D. W. T.: Synthetic calibration and quantitative analysis of gas-phase FT-IR spectra, Appl. Spectrosc., 50, 59-70, 1996.
Griffith, D. W. T., Deutscher, N. M., Caldow, C., Kettlewell, G., Riggenbach, M., and Hammer, S.: A Fourier transform infrared trace gas and isotope analyser for atmospheric applications, Atmos. Meas. Tech., 5, 2481-2498, https://doi.org/10.5194/amt-52481-2012, 2012.

Guieu, C., Bonnet, S., Wagener, T., and Loÿe-Pilot, M. D.: Biomass burning as a source of dissolved iron to the open ocean?, Geophys. Res. Lett., 32, https://doi.org/10.1029/2005GL022962, 2005.

Gustin, M. S., Lindberg, S. E., and Weisberg, P. J.: An update on the natural sources and sinks of atmospheric mercury, Appl. Geochem., 23, 482-493, 2008.

Hönninger, G., von Friedeburg, C., and Platt, U.: Multi axis differential optical absorption spectroscopy (MAX-DOAS), Atmos. Chem. Phys., 4, 231-254, https://doi.org/10.5194/acp-4231-2004, 2004.

Howard, D., Nelson, P. F., Edwards, G. C., Morrison, A. L., Fisher, J. A., Ward, J., Harnwell, J., van der Schoot, M., Atkinson, B., Chambers, S. D., Griffiths, A. D., Werczynski, S., and Williams, A. G.: Atmospheric mercury in the Southern Hemisphere tropics: seasonal and diurnal variations and influence of inter-hemispheric transport, Atmos. Chem. Phys., 17, 1162311636, https://doi.org/10.5194/acp-17-11623-2017, 2017.

Iinuma, Y., Engling, G., Puxbaum, H., and Herrmann, H.: A highly resolved anion-exchange chromatographic method for determination of saccharidic tracers for biomass combustion and primary bio-particles in atmospheric aerosol, Atmos. Environ., 43, 13671371, 2009.

Ito, A.: Mega fire emissions in Siberia: potential supply of bioavailable iron from forests to the ocean, Biogeosciences, 8, 16791697, https://doi.org/10.5194/bg-8-1679-2011, 2011.

Jacobson, M. Z.: Strong radiative heating due to the mixing state of black carbon in atmospheric aerosols, Nature, 409, 695-697, 2001.

Johnson, G. R., Ristovski, Z., and Morawska, L.: Method for measuring the hygroscopic behaviour of lower volatility fractions in an internally mixed aerosol, J. Aerosol Sci., 35, 443-455, https://doi.org/10.1029/2004GL020126, 2004.

Kaiser, J. W. and Keywood, M.: Preface for Atmos. Env. Special issue on IBBI, Atmos. Environ., 121, 1-3, 2015.

Keil, A. and Haywood, J. M.: Solar radiative forcing by biomass burning aerosol particles during SAFARI 2000: A case study based on measured aerosol and cloud properties, J. Geophys. Res.-Atmos., 108, https://doi.org/10.1029/2002JD002315, 2003.

Keywood, M., Kanakidou, M., Stohl, A., Dentener, F., Grassi, G., Meyer, C. P., Torseth, K., Edwards, D., Thompson, A. M., Lohmann, U., and Burrows, J.: Fire in the air: Biomass burning impacts in a changing climate, Crit. Rev. Environ. Sci. Tec., 43, 40-83, 2013.

Konovalov, I., Beekmann, M., Berezin, E., Petetin, H., Mielonen, T., Kuznetsova, I., and Andreae, M.: The role of semi-volatile organic compounds in the mesoscale evolution of biomass burning aerosol: a modeling case study of the 2010 mega-fire event in Russia, Atmospheric Chemistry and Physics, 15, 13269-13297, https://doi.org/10.5194/acp-15-13269-2015, 2015.

Landis, M. S., Stevens, R. K., Schaedlich, F., and Prestbo, E. M.: Development and characterization of an annular denuder methodology for the measurement of divalent inorganic reac- 
tive gaseous mercury in ambient air, Environ. Sci. Technol., 36, 3000-3009, 2002.

LaRoche, J. and Breitbarth, E.: Importance of the diazotrophs as a source of new nitrogen in the ocean, J. Sea Res., 53, 67-91, 2005.

Lawson, S. J., Keywood, M. D., Galbally, I. E., Gras, J. L., Cainey, J. M., Cope, M. E., Krummel, P. B., Fraser, P. J., Steele, L. P., Bentley, S. T., Meyer, C. P., Ristovski, Z., and Goldstein, A. H.: Biomass burning emissions of trace gases and particles in marine air at Cape Grim, Tasmania, Atmos. Chem. Phys., 15, 1339313411, https://doi.org/10.5194/acp-15-13393-2015, 2015.

Lin, N.-H., Tsay, S.-C., Maring, H. B., Yen, M.-C., Sheu, G.-R., Wang, S.-H., Chi, K. H., Chuang, M.-T., Ou-Yang, C.-F., and Fu, J. S.: An overview of regional experiments on biomass burning aerosols and related pollutants in Southeast Asia: From BASEASIA and the Dongsha Experiment to 7-SEAS, Atmos. Environ., 78, 1-19, 2013.

Liousse, C., Devaux, C., Dulac, F., and Cachier, H.: Aging of savanna biomass burning aerosols: Consequences on their optical properties, J. Atmos. Chem., 22, 1-17, 1995.

Mallet, M. D., Cravigan, L. T., Milic, A., Alroe, J., Ristovski, Z. D., Ward, J., Keywood, M., Williams, L. R., Selleck, P., and Miljevic, B.: Composition, size and cloud condensation nuclei activity of biomass burning aerosol from northern Australian savannah fires, Atmos. Chem. Phys., 17, 3605-3617, https://doi.org/10.5194/acp-17-3605-2017, 2017.

Manninen, H. E., Petaja, T., Asmi, E., Riipinen, I., Nieminen, T., Mikkila, J., Horrak, U., Mirme, A., Mirme, S., Laakso, L., Kerminen, V. M., and Kulmala, M.: Long-term field measurements of charged and neutral clusters using Neutral cluster and Air Ion Spectrometer (NAIS), Boreal Environ. Res., 14, 591-605, 2009.

Meyer, C., Cook, G., Reisen, F., Smith, T., Tattaris, M., RussellSmith, J., Maier, S., Yates, C., and Wooster, M.: Direct measurements of the seasonality of emission factors from savanna fires in northern Australia, J. Geophys. Res.-Atmos., 117, 2012.

Meyer, C. P., Luhar, A. K., and Mitchell, R. M.: Biomass burning emissions over northern Australia constrained by aerosol measurements: I-Modelling the distribution of hourly emissions, Atmos. Environ., 42, 1629-1646, 2008.

Milic, A., Mallet, M. D., Cravigan, L. T., Alroe, J., Ristovski, Z. D., Selleck, P., Lawson, S. J., Ward, J., Desservettaz, M. J., and Paton-Walsh, C.: Biomass burning and biogenic aerosols in northern Australia during the SAFIRED campaign, Atmos. Chem. Phys., 17, 3945-3961, https://doi.org/10.5194/acp-173945-2017, 2017.

Mirme, A., Tamm, E., Mordas, G., Vana, M., Uin, J., Mirme, S., Bernotas, T., Laakso, L., Hirsikko, A., and Kulmala, M.: A widerange multi-channel Air Ion Spectrometer, Boreal Environ. Res., 12, 247-264, 2007.

National Environment Protection Council Service Corporation: National Environment Protection (Air Toxics) Measure, 2011.

Paris, R., Desboeufs, K. V., Formenti, P., Nava, S., and Chou, C.: Chemical characterisation of iron in dust and biomass burning aerosols during AMMA-SOP0/DABEX: implication for iron solubility, Atmos. Chem. Phys., 10, 4273-4282, https://doi.org/10.5194/acp-10-4273-2010, 2010.

Penner, J., Chuang, C., and Grant, K.: Climate forcing by carbonaceous and sulfate aerosols, Clim. Dynam., 14, 839-851, 1998.

Rea, A. W., Lindberg, S. E., Scherbatskoy, T., and Keeler, G. J.: Mercury accumulation in foliage over time in two north- ern mixed-hardwood forests, Water Air Soil Pollut., 133, 49-67, 2002.

Russell-Smith, J., Yates, C. P., Whitehead, P. J., Smith, R., Craig, R., Allan, G. E., Thackway, R., Frakes, I., Cridland, S., Meyer, M. C. P., and Gill, M.: Bushfires' down under': patterns and implications of contemporary Australian landscape burning, Int. J. Wildland Fire, 16, 361-377, 2007.

Russell-Smith, J., Cook, G. D., Cooke, P. M., Edwards, A. C., Lendrum, M., Meyer, C., and Whitehead, P. J.: Managing fire regimes in north Australian savannas: applying Aboriginal approaches to contemporary global problems, Front. Ecol. Environ., 11, e55-e63, 2013.

Saarikoski, S., Sillanpää, M., Sofiev, M., Timonen, H., Saarnio, K., Teinilä, K., Karppinen, A., Kukkonen, J., and Hillamo, R.: Chemical composition of aerosols during a major biomass burning episode over northern Europe in spring 2006: Experimental and modelling assessments, Atmos. Environ., 41, 3577-3589, 2007.

Sedwick, P. N., Sholkovitz, E. R., and Church, T. M.: Impact of anthropogenic combustion emissions on the fractional solubility of aerosol iron: Evidence from the Sargasso Sea, Geochem. Geophy., Geosy., 8, https://doi.org/10.1029/2007GC001586, 2007.

Shi, Y., Matsunaga, T., Saito, M., Yamaguchi, Y., and Chen, $\mathrm{X}$.: Comparison of global inventories of $\mathrm{CO}_{2}$ emissions from biomass burning during 2002-2011 derived from multiple satellite products, Environ. Pollut., 206, 479-487, 2015.

Singh, H., Brune, W., Crawford, J., Jacob, D. J., and Russell, P.: Overview of the summer 2004 Intercontinental Chemical Transport Experiment-North America (INTEX-A), J. Geophys. Res.Atmos., 111, https://doi.org/10.1029/2006JD007905, 2006.

Sinreich, R., Friess, U., Wagner, T., and Platt, U.: Multi axis differential optical absorption spectroscopy (MAX-DOAS) of gas and aerosol distributions, Faraday Discuss., 130, 153-164, 2005.

Sprovieri, F., Pirrone, N., Bencardino, M., D’Amore, F., Carbone, F., Cinnirella, S., Mannarino, V., Landis, M., Ebinghaus, R., Weigelt, A., Brunke, E.-G., Labuschagne, C., Martin, L., Munthe, J., Wängberg, I., Artaxo, P., Morais, F., Barbosa, H. D. M. J., Brito, J., Cairns, W., Barbante, C., Diéguez, M. D. C., Garcia, P. E., Dommergue, A., Angot, H., Magand, O., Skov, H., Horvat, M., Kotnik, J., Read, K. A., Neves, L. M., Gawlik, B. M., Sena, F., Mashyanov, N., Obolkin, V., Wip, D., Feng, X. B., Zhang, H., Fu, X., Ramachandran, R., Cossa, D., Knoery, J., Marusczak, N., Nerentorp, M., and Norstrom, C.: Atmospheric mercury concentrations observed at groundbased monitoring sites globally distributed in the framework of the GMOS network, Atmos. Chem. Phys., 16, 11915-11935, https://doi.org/10.5194/acp-16-11915-2016, 2016.

Steffen, A., Douglas, T., Amyot, M., Ariya, P., Aspmo, K., Berg, T., Bottenheim, J., Brooks, S., Cobbett, F., Dastoor, A., Dommergue, A., Ebinghaus, R., Ferrari, C., Gardfeldt, K., Goodsite, M. E., Lean, D., Poulain, A. J., Scherz, C., Skov, H., Sommar, J., and Temme, C.: A synthesis of atmospheric mercury depletion event chemistry in the atmosphere and snow, Atmos. Chem. Phys., 8, 1445-1482, https://doi.org/10.5194/acp-8-1445-2008, 2008.

Stockwell, C. E., Yokelson, R. J., Kreidenweis, S. M., Robinson, A. L., DeMott, P. J., Sullivan, R. C., Reardon, J., Ryan, K. C., Griffith, D. W. T., and Stevens, L.: Trace gas emissions from combustion of peat, crop residue, domestic biofuels, grasses, and other fuels: configuration and Fourier transform 
infrared (FTIR) component of the fourth Fire Lab at Missoula Experiment (FLAME-4), Atmos. Chem. Phys., 14, 9727-9754, https://doi.org/10.5194/acp-14-9727-2014, 2014.

Tuch, T. M., Haudek, A., Müller, T., Nowak, A., Wex, H., and Wiedensohler, A.: Design and performance of an automatic regenerating adsorption aerosol dryer for continuous operation at monitoring sites, Atmos. Meas. Tech., 2, 417-422, https://doi.org/10.5194/amt-2-417-2009, 2009.

van der Werf, G. R., Randerson, J. T., Giglio, L., Collatz, G. J., Mu, M., Kasibhatla, P. S., Morton, D. C., DeFries, R. S., Jin, Y., a nd van Leeuwen, T. T.: Global fire emissions and the contribution of deforestation, savanna, forest, agricultural, and peat fires (1997-2009), Atmos. Chem. Phys., 10, 11707-11735, https://doi.org/10.5194/acp-10-11707-2010, 2010.

Wang, X., Thai, P. K., Mallet, M., Desservettaz, M., Hawker, D. W., Keywood, M., Miljevic, B., Paton-Walsh, C., Gallen, M., and Mueller, J. F.: Emissions of selected semivolatile organic chemicals from forest and savannah fires, Environ. Sci. Technol., 51, 1293-1302, 2017.

Whittlestone, S. and Zahorowski, W.: Baseline radon detectors for shipboard use: Development and deployment in the First Aerosol Characterization Experiment (ACE 1), J. Geophys. Res.-Atmos., 103, 16743-16751, 1998.

Winton, V., Bowie, A., Edwards, R., Keywood, M., Townsend, A., van der Merwe, P., and Bollhöfer, A.: Fractional iron solubility of atmospheric iron inputs to the Southern Ocean, Mar. Chem., 177, 20-32, 2015.
Winton, V. H. L., Edwards, R., Bowie, A. R., Keywood, M., Williams, A. G., Chambers, S. D., Selleck, P. W., Desservettaz, M., Mallet, M. D., and Paton-Walsh, C.: Dry season aerosol iron solubility in tropical northern Australia, Atmos. Chem. Phys., 16, 12829-12848, https://doi.org/10.5194/acp-16-128292016, 2016.

Wong, J. and Li, Z.: Retrieval of optical depth for heavy smoke aerosol plumes: uncertainties and sensitivities to the optical properties, J. Atmos. Sci., 59, 250-261, 2002.

Yokelson, R. J., Crounse, J. D., DeCarlo, P. F., Karl, T., Urbanski, S., Atlas, E., Campos, T., Shinozuka, Y., Kapustin, V., Clarke, A. D., Weinheimer, A., Knapp, D. J., Montzka, D. D., Holloway, J., Weibring, P., Flocke, F., Zheng, W., Toohey, D., Wennberg, P. O., Wiedinmyer, C., Mauldin, L., Fried, A., Richter, D., Walega, J., Jimenez, J. L., Adachi, K., Buseck, P. R., Hall, S. R., and Shetter, R.: Emissions from biomass burning in the Yucatan, Atmos. Chem. Phys., 9, 5785-5812, https://doi.org/10.5194/acp-9-57852009, 2009. 